戦略的創造研究推進事業

（社会技術研究開発）

研究開発実施終了報告書

\title{
「持続可能な多世代共創社会のデザイン」 研究開発領域
}

\author{
研究開発プロジェクト \\ 「ジェネラティビティで紡ぐ重層的な地域多世代 \\ 共助システムの開発」
}

研究開発期間 平成 27 年 10 月～平成 31 年 3 月 研究代表者 藤原 佳典

（東京都健康長寿医療センター研究所 研究部長） 


\section{目次}

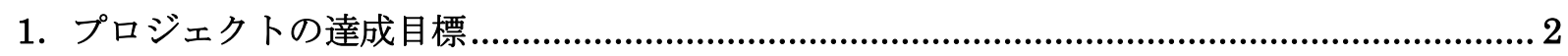

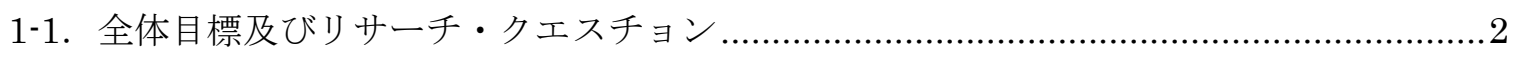

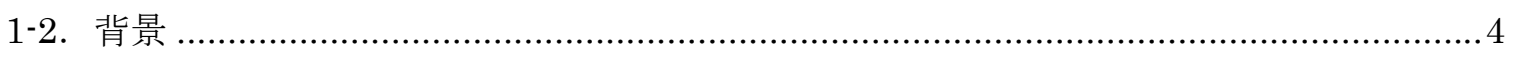

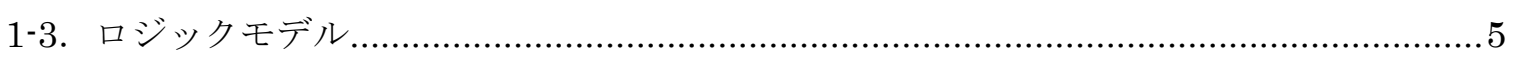

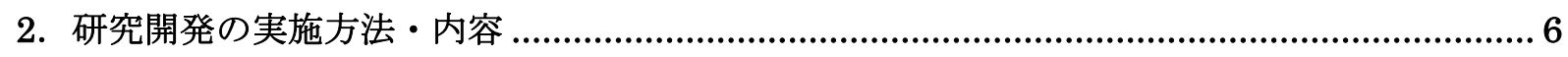

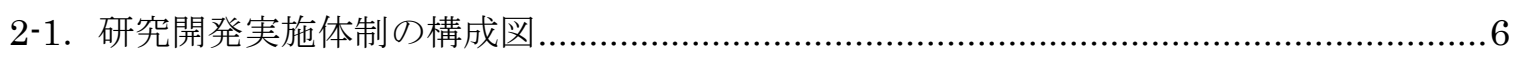

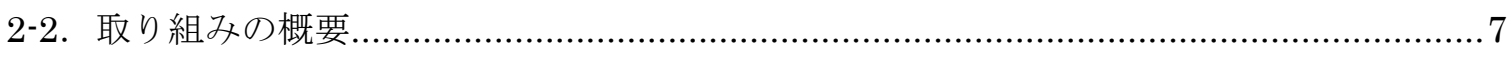

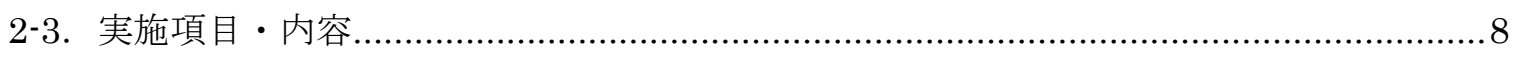

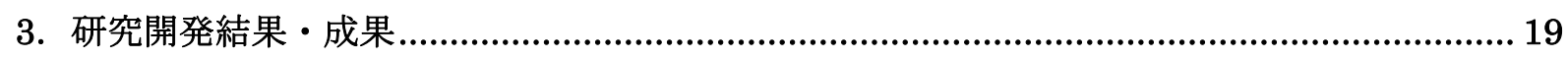

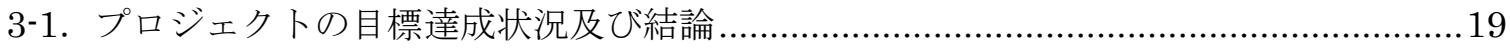

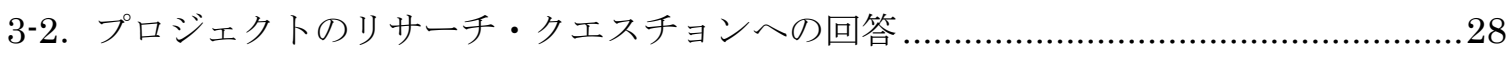

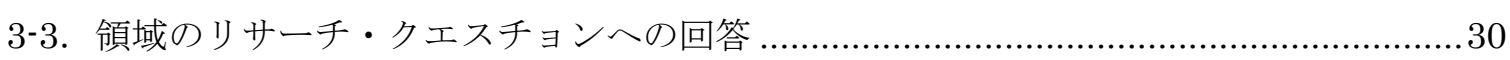

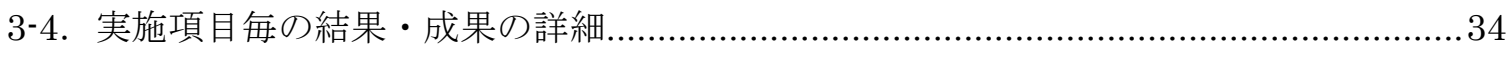

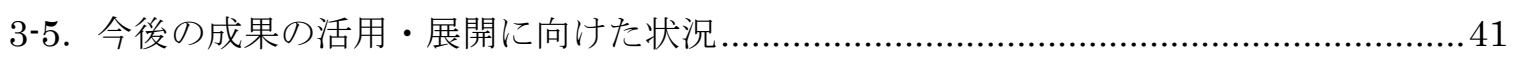

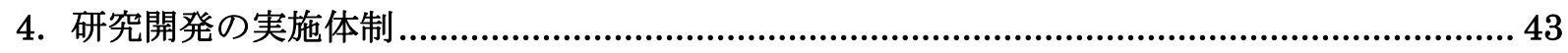

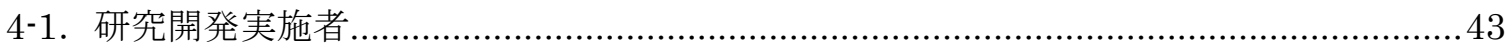

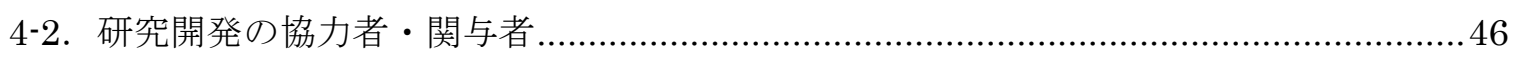

5. 研究開発成果の発表・発信状況、アウトリーチ活動など ..................................................... 47

5-1. 社会に向けた情報発信状況、アウトリーチ活動など ................................................. 47

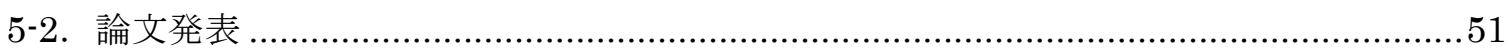

5-3. 口頭発表（国際学会発表及び主要な国内学会発表） ……........................................52

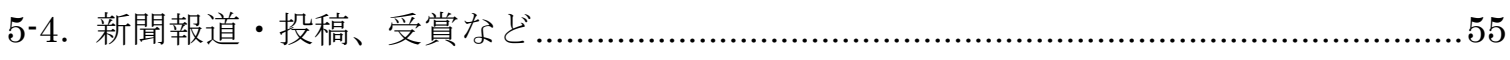

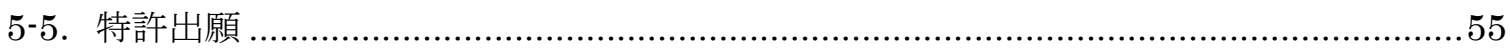




\section{1.プロジェクトの達成目標}

\section{1-1．全体目標及びリサーチ・クエスチョン}

本プロジェクトで目指す最終的なビジョンは、「子どもの健やかな成長の喜びを全ての世代が共 有できるまちづくり」である。本プロジェクトでは、将来への時間軸としてのジェネラティビテ イ（次世代継承への意識・行動）をその価值観として市民が共有すべきと考える。そのためには、 子育て世代と中高年世代が他世代のニーズも理解し相互扶助の精神を共有する必要がある。子育 て世代にとっては、託児等の支援が必要であり、一方、次世代への支援を期待される高齢者世代 にとっては、まずは自身の生活自立の延伸が最優先課題である。日常生活の互助により高齢者の 自立生活を維持することは国家予算の多くを占める高齡者のための社会保障費 (医療費・介護費) の軽減、それによる保育・教育費への転嫁という点で間接的な次世代支援ともいえる。

このような実質的な課題を同時に解決する研究開発活動として、本プロジェクトでは東京都北 区志茂地区および神奈川県川崎市多摩区中野島地区にて、情緒的相互支援（日常的な声かけやあ いさつ運動など）による緩やかなサポートネットワークの形成、多世代交流の場やプログラムに よる社会参加支援、子育て世代と高齢者の生活支援をマッチングする多様な仕掛けや仕組みを基 盤とした多世代住民間互助の確立に取り組んでいる。これら 3 層からなる地域多世代共助システ ムの取り組みは、生活線上での多世代交流機会の増加だけでなく、情緒的・手段的相互支援や、 生活困窮家族においては生活基盤や就労状況の改善といった短期的アウトカムにつながることが 見込まれる。その結果、長期的アウトカムとしてジェネラティビティの共有・確立にも結びつく と考えている。

$<$ 達成目標 $>$

○達成目標 1 ：世代間の緩やかなサポートネットワークの形成による世代間の信頼の高まり

目標：子育てや高齢者分野で活動している既存の住民ボランティアにジェネラティビティを啓発 する研修を実施し、高齢者と子ども・子育て世代の間で、声かけや見守りの支援が相互に なされる世代間の緩やかなサポートネットワークが形成される「中高年から始める多世代 挨拶運動（以降、多世代挨拶運動）」活動を実装する。それにより一般の大勢の住民の中で 緩やかなサポートネットワーク形成による世代間の信頼感の高まりを期待する。

○達成目標 2 : 多世代交流を基盤とした多世代住民間互助の確立

北区志茂地区と川崎市多摩区の両モデル地区にて、「まち・人・くらしプロモーター(まちプロ)」 を担い手とし、地域の関連機関（子育て支援センター、地域包括支援センター、社会福祉協議会 (以降社協) 等)、NPO や企業等と連携し、多世代交流プログラムを企画・運営する。多世代交流 の場において当事者同士で助け合いに関するマッチングを行える仕掛けや仕組みを開発する。ま ちプロは交流プログラム内で、参加者同士の交流と助け合いを促す「つなぎ役」となる。

多世代交流プログラムを基盤とした互助の仕組みづくりにより達成が期待される成果として、

1）日常生活の延長線上での気軽な手段的相互支援の授受促進、および、2）地域の多世代住民間 での交流機会の増加によるジェネラティビティの醸成である。

○達成目標 3 : 多様な背景をもつ子どもへの学習・居場所支援による生活基盤の改善 目標 : 平成 27 年度に実施した先行研究レビューおよび事例調査を踏まえ設定目標を、多様な背景 をもつ子じもに対する学習支援および居場所支援により生活困窮家庭を含む多様な背景を持つ家 
庭を多世代の住民間で緩やかに支援する生活支援サービス提供モデルおよび多世代交流プログラ ムの開発へ変更した。具体的には、多世代交流の場とそこで生まれる互助（新達成目標 2）に、多 様な背景をもつ子どもとその保護者も自然に参画できることを目指す。

\section{くリサーチ・クエスチョン>}

(達成目標 1 に対して)

Q1. 地域における世代間の信頼感は，世代間の緩やかなサポートネットワークを形成することに より高めることが出来るのか?

(達成目標 2 に対して)

Q2. 多世代交流の場にて、高齢者世代と子育て世代が何らかの協働作業を積み重㸚るプログラム とその中で両世代を積極的に繋ぐ人材がいれば、両世代の交流が発生するのか?

Q3. 多世代交流の場にて、個人の生活上の課題を顕在化させる仕掛けがあれば、支援ニーズは顕 在化するのか?

Q4. 顕在化したニーズは、他者への支援を求める仕掛けがあれば交流プログラム内で互助のマッ チングは成立するのか?

Q5. 子育て世代ならではの高齢者支援とは何か

Q6. 高齢者世代が抵抗感なく参画できる子育て支援と何か

（達成目標 3 に対して）

Q7. 多様な背景をもつ子どもへの居場所・学習支援の充実は，困窮家庭の生活基盤の改善につな がるのか?

（達成目標 $1 、 2 、 3$ に対して）

Q8. 各協議会メンバーとその所属団体にとって他分野との連携が自組織の活動にメリットがある 事を実感・認識すれば、横断的連携が醸成・維持されるのか?

Q9. 多分野の組織が多世代共創を目的としたプログラムやイベントの開発・運営において協㗢す ることで、横断的連携は進むか? 


\section{1-2. 背景}

わが国は今後、急速な少子高齢化や人口減少、財政縮小が予想される。市町村が安定した施策 を持続するためには社会保障費の増大を抑制する策を講じる必要がある。平成 24 年、国は社会保 障制度の持続のためにその基盤を維持する少子化対策を就労、結婚、妊娠、出産、育児の各段階 に応じて切れ目なく支援する「子ども子育て支援法」を制定した。高齢者支援においては、平成 27 年度より施行された介護予防・日常生活支援総合事業（総合事業）により、高齢者の日常生活 を介護保険制度外で支える仕組みの拡充が進められることとなった。しかし、その財源確保のた めには医療・介護給付費の伸びを抑制し、財源を子育て支援と高齢者施策に有効に配分寸る必要 がある。これらの国策は市町村の裁量で具現化されるよう法整備は進しでいる。しかしながら、 保健福祉分野で先進的なモデルをいち早く実装してきた自治体においても、子ども・子育て支援 策や高齢者施策の推進を阻害する共通のボトルネックが存在する。それは、限られた財政の下、 多様で複雑化した子育て世代と激増寸る中高年世代の生活課題を支援できる資源や人材の確保で ある。その解決策は資源や人材を世代別から多世代対応一統合し集中することである。更に統合 と集中のボトルネックは、行政施策の過度な縦割りに加えて、互助共助においては社会保障負担 の世代間格差のもと、自己の世代の利益のみを優先しようとする潜在的な「世代間対立」と考え る。逆に、全ての世代が統合と集中に合意・協調してこそシナジー効果が得られる。しかし、核 家族化等の影響により多世代が交流する機会が減少する現在では、新たな世代間共創の価值観と それに基づく仕掛けを創出する必要がある。 


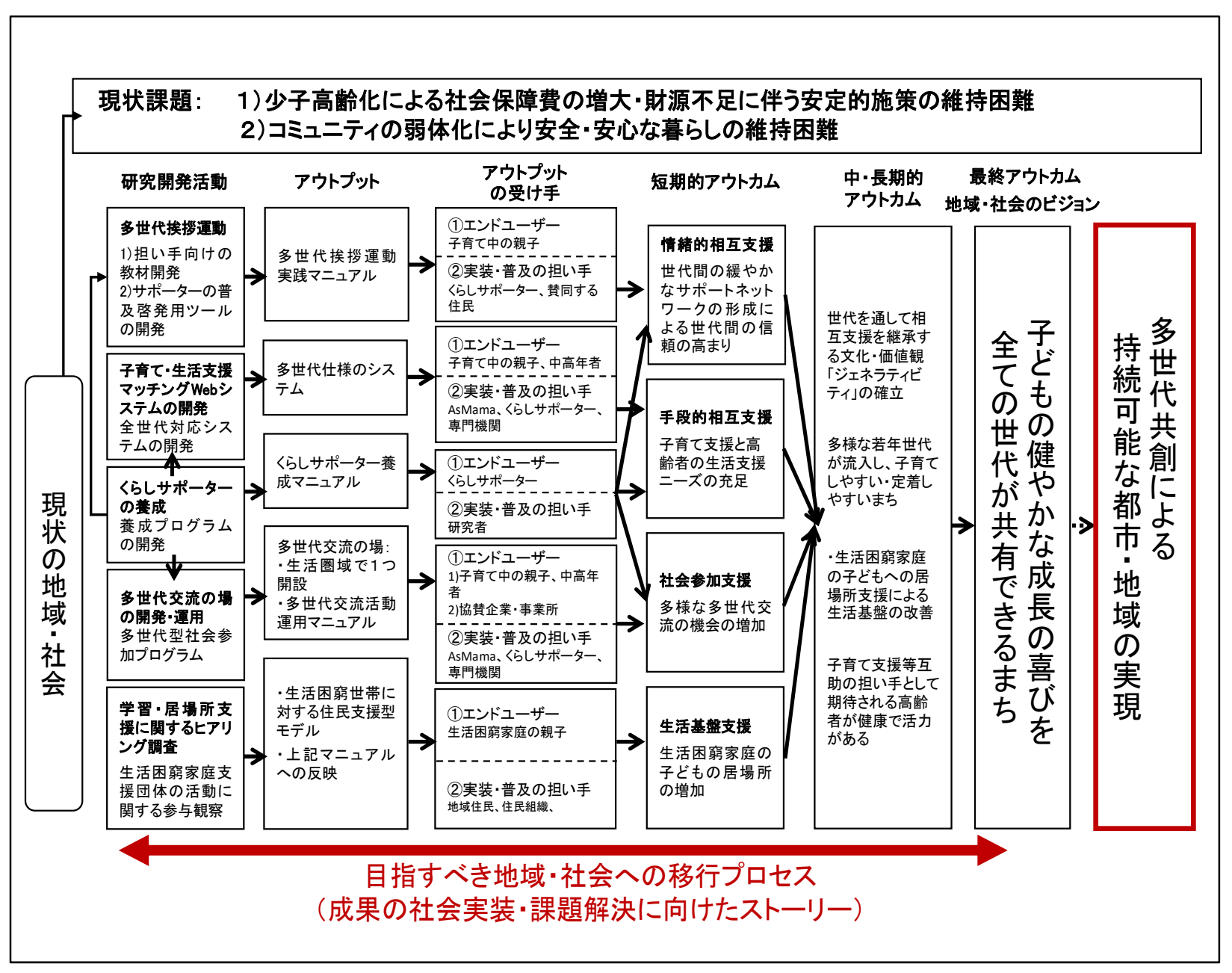




\section{2. 研究開発の実施方法・内容}

\section{2-1. 研究開発実施体制の構成図}

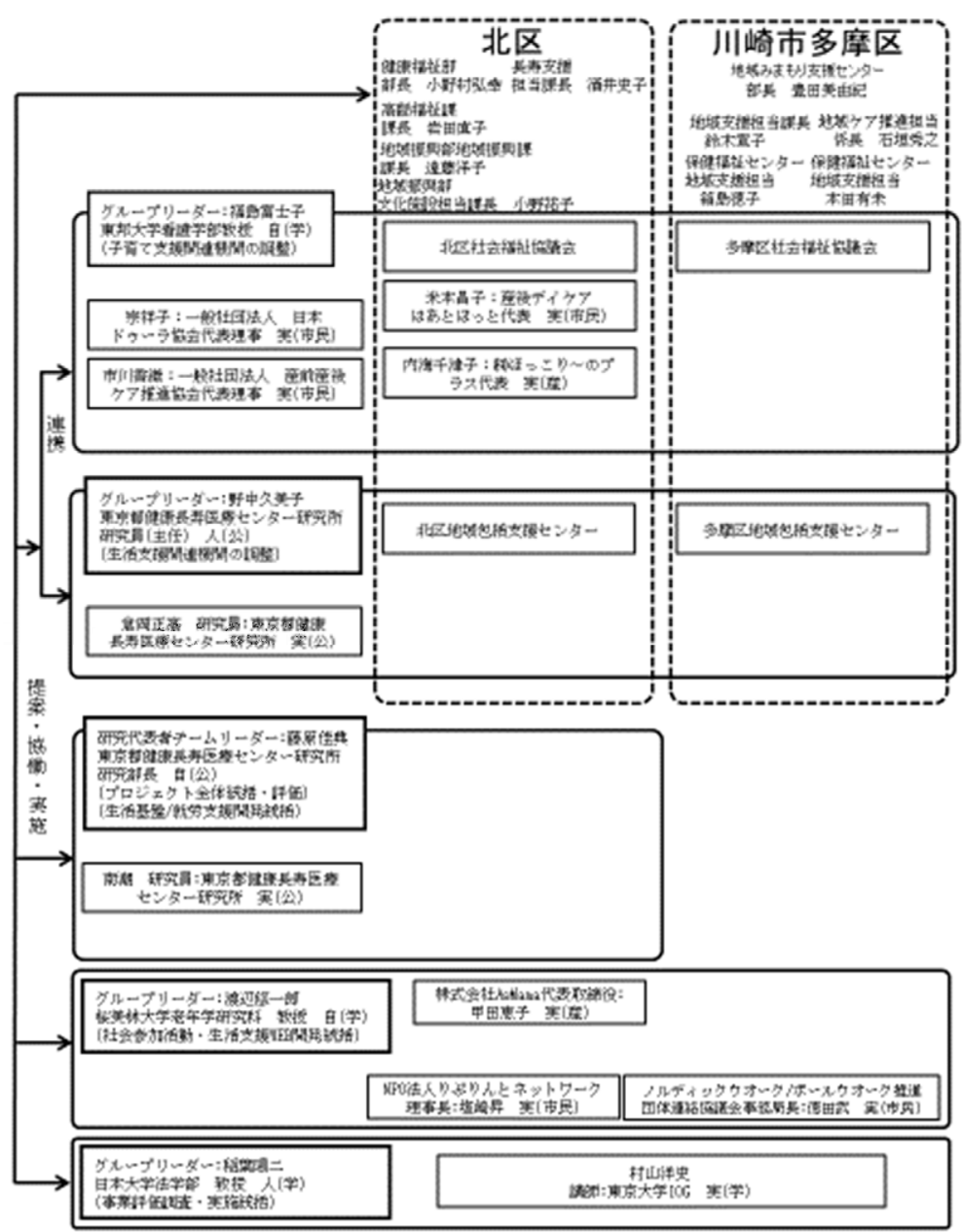

\begin{tabular}{|l|l|}
\hline \multicolumn{1}{|c|}{ 氏名 所属 役職 (または組織名) } & \multicolumn{1}{|c|}{ 協力内容 } \\
\hline 北区役所 長寿支援課長 酒井史子 & $\begin{array}{l}\text { 協議会・多世代交流プログラム・生活支援 Web シス } \\
\text { テム開発にかかる調整 }\end{array}$ \\
\hline 北区役所 地域振興課課長 遠藤洋子 & $\begin{array}{l}\text { 協議会・多世代交流プログラム・生活支援 Web シス } \\
\text { テム開発にかかる調整 }\end{array}$ \\
\hline 北区 志茂町会自治会連合会会長 齋藤邦彦 & 多世代推進会議（志茂ジェネ協議会）の運営 \\
\hline $\begin{array}{l}\text { 多摩区役所地域みまもり支援センター } \\
\text { 地域支援担当課長 鈴木宣子 }\end{array}$ & $\begin{array}{l}\text { 協議会・多世代交流プログラム・生活支援 Web シス } \\
\text { テム開発にかかる調整 }\end{array}$ \\
\hline $\begin{array}{l}\text { 多摩区役所地域みまもり支援センター } \\
\text { 地域支援担当 箱島徳子 }\end{array}$ & $\begin{array}{l}\text { 協議会・多世代交流プログラム・生活支援 Web シス } \\
\text { テム開発にかかる調整 }\end{array}$ \\
\hline 多摩区中野島地区社会福祉協議会会長田村弘志 & $\begin{array}{l}\text { 多摩区中野島地区多世代推進会議（中野島多世代つな } \\
\text { がり愛プロジェクト協議会）の運営 }\end{array}$ \\
\hline
\end{tabular}




\section{2-2. 取り組みの概要}

本プロジェクトでは、「子育てに関する地域の理解や許容不足」「「出会いのきっかけ不足や社会 的孤立」、「緊急時や日常生活の支援」といった、特に高齢者と子育て世代が抱える課題を解決す るため、図 1 の通り重層的な地域多世代共助システムの開発と実装を行なっている。

第一に、心の支え合い（情緒的支援）として、世代間による挨拶運動やキャンペーンを通して 声かけや見守りによる「ゆるやかなつながり」を目指している。第二に、交流と居場所づくり（社 会参加）として、多世代交流プログラムや居場所を展開し、地域の子育て世代と高齢者世代が顔 見知りになり、信頼関係が構築されるようなプログラムを展開している。第三に、両世代がお互 いに、日常生活における困り事を支え合う（手段的支援）ことが出来るような仕掛けや仕組みづ くりを目指している。

これら 3 つの取り組みを重層的に地域で行うサポーターとして、まち・人・くらしプロモータ 一（通称まちプロ）が、多世代交流プログラムや居場所の企画や運営、参加者をつなげる活動を 担っている。また、各モデル地区にて、行政機関、地縁組織、民間企業などから構成される協議 会が運営されており、プロジェクトの目標にもとづいた実施計画の策定から、必要な広報やまち プロの支援、各プログラムの推進、実施事項の評価と改善（PDCA サイクルの回転）を行っている。

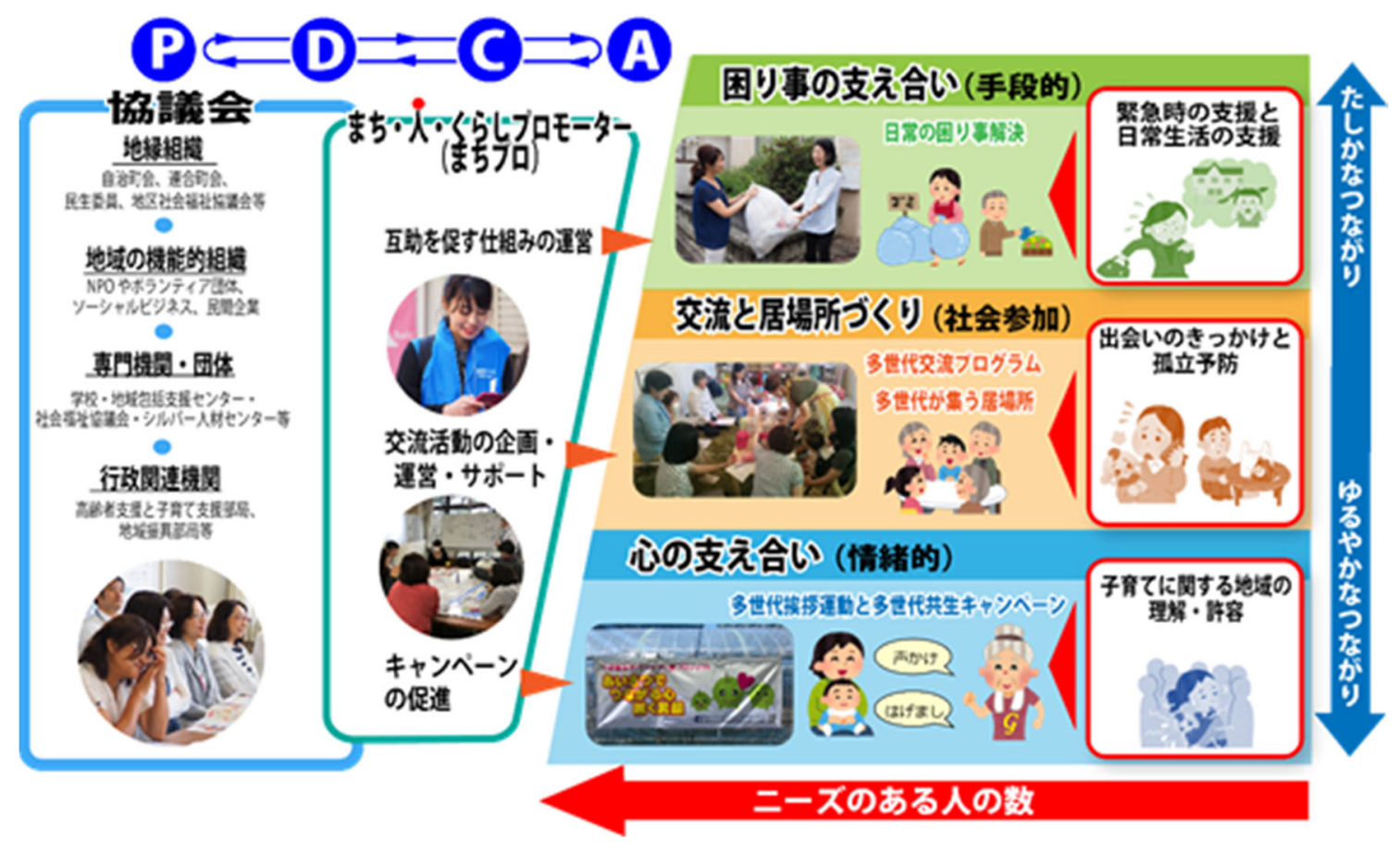

図 1 重層的な地域多世代共助システムと協議会・まちプロの関係 


\section{2-3．実施項目・内容}

\section{2-3-1．中高年から始める多世代挨拶運動}

○達成目標 1 [情緒的相互支援］：世代間の緩やかなサポートネットワークの形成による世代間の 信頼の高まり

目的 : 子育てや高齢者分野で活動している既存の住民ボランティアにジェネラティビティを啓発 する研修を実施し、高齢者と子ども・子育て世代の間で、声かけや見守りの支援が相互になされ る世代間の緩やかなサポートネットワークが形成される「中高年から始める多世代挨拶運動（以 降、多世代挨拶運動)」活動を実装する。それにより一般の大勢の住民の中で緩やかなサポートネ ットワーク形成による世代間の信頼感の高まりを期待する。

実施内容 :

【2 地区共通の実施事項】

・ ジェネラティビティの醸成と本プロジェクトの PR を目的としたリストバンド 300 個 （写真 1 ）を製作し、地域のイベントや各種地域活動団体の定例会などで配布した。

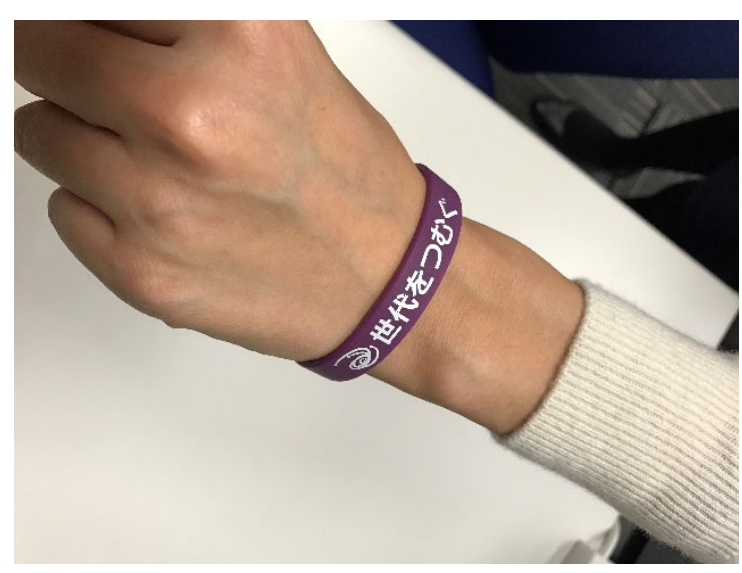

\section{写真 1 プロジェクトPR用のリストバンド}

- 両モデル地区にて、地域内の小・中学校に通う児童・生徒を対象に、本プロジェクトの PRに 活用可能なロゴマーク（対象校は、北区：小学校 2 校・中学校 1 校、多摩区：小学校 2 校） と標語（対象校は、多摩区：中学校 1 校）を募集し、協議会にて優秀作品を審查・決定した。

・ 上記のロゴマークと標語を使用したグッズを製作し、本プロジェクトの普及啓発を推進した。 両地区に共通した取り組みとして、ロゴマークを記載したクリアファイル（写真 2）を作成 し、地域内の全校児童・生徒に配布したほか、地域のイベントや各種地域活動団体の定例会 などでも配布を行った。 

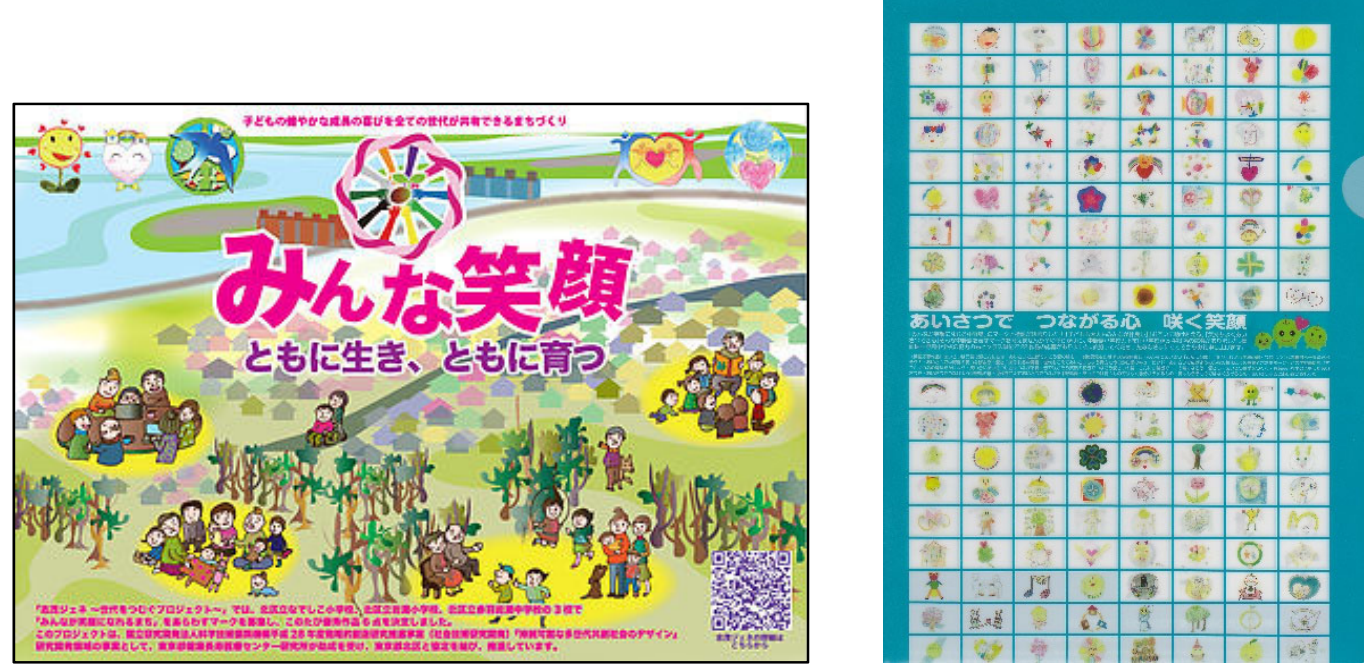

\section{写真 2 プロジェクトPR用のクリアファイル（左：北区志茂、右 : 多摩区中野島）}

- 多世代交流プログラムの企画と運営、および交流を基盤とした互助を促す「まち・人・くら しプロモーター」(通称：まちプロ）の着用グッズ（北区はベスト、多摩区はビブス）を作成 し、イベント等でのプロジェクトPR時に活用した。

- 北区及び多摩区でのキャンペーン推進ツールとして、Facebookページおよびプロジェクト紹 介用のウェブサイトを作成し、それぞれの地域での活動状況や住民インタビューなどをまと めた動画を作成・掲載した。

Facebook URL（北区・多摩区共通）：https://www.facebook.com/ristexgenerativity/ 北区ウェブサイトURL : https://i10vinkotobuki.wixsite.com/mysiteshimogene

多摩区Facebook URL（中野島ファミリーカフェ）:

https://www.facebook.com/中野島ファミリーカフェ-257333311681117/

※多摩区においては、まちプロが多世代交流イベントの開催情報を Facebook ページにて

発信し、イベントの告知および実施報告をしている。

- 本プロジェクトおよび挨拶運動の学校への波及効果を検証することを目的として、平成28年 度および平成30年3月に児童・保護者・教職員を対象とした無記名自記式調查を実施した（北 区は対象校の都合により、平成28年度の調査のみ実施)。

\section{【北区での実施内容】}

- プロジェクト期間中の年度ごとに、町会・自治会（町会長会議と、各町会・自治会の役員・定 例会）、民生委員児童委員協議会、青少年地区委員会役員会にて、ジェネラティビティを啓 発する 15 分程度のミニ講座とプロジェクトの PR を行い、その中で挨拶運動も周知した。

・ 本プロジェクトの目的に賛同し、地域で挨拶を実践する住民ボランティアを「あいさつさん」 として募集した（登録制）。また、「あいさつさん」の活動時の着用グッズとしてネックスト ラップ (写真 3) を製作し、登録者に配布した。

- 地域包括支援センターの全職員が「あいさつさん」のストラップを常時着用し、高齢者を主 な対象として、当該活動の周知を行っている。

- 個人単位での募集とあわせて、志茂地区の各地域活動団体に団体単位での「あいさつさん」 活動への参画を呼びかけ、町会・自治会、青少地区委員会、民生委員児童委員協議会から内 
諾を得た。平成 $29 \cdot 30$ 年度には、青少年地区委員会と連携し、北区なでしこ小学校で開催さ れているラジオ体操（7 月 21 日〜30日）で「あいさつさん」の活動について大規模な PR を 行った。青少年地区委員会のメンバーはラジオ体操の開催期間中、上記のネックストラップ を常時着用し、子どもたちや保護者に対する挨拶を実践した。同様の取り組みを志茂ゆりの 木公園会場でも実施した。

- 平成 30 年 6 月より、毎月第 2 金曜日に「あいさつさん」定例会（月例会合）を設置し、志茂 地域振興室・志茂ふれあい館にて定期開催を始めた。定例会は、前半で「あいさつさん」の 活動での気付きや課題についてミーティングを行い、後半では実際に地域に出てチームで挨 拶運動を行っている。

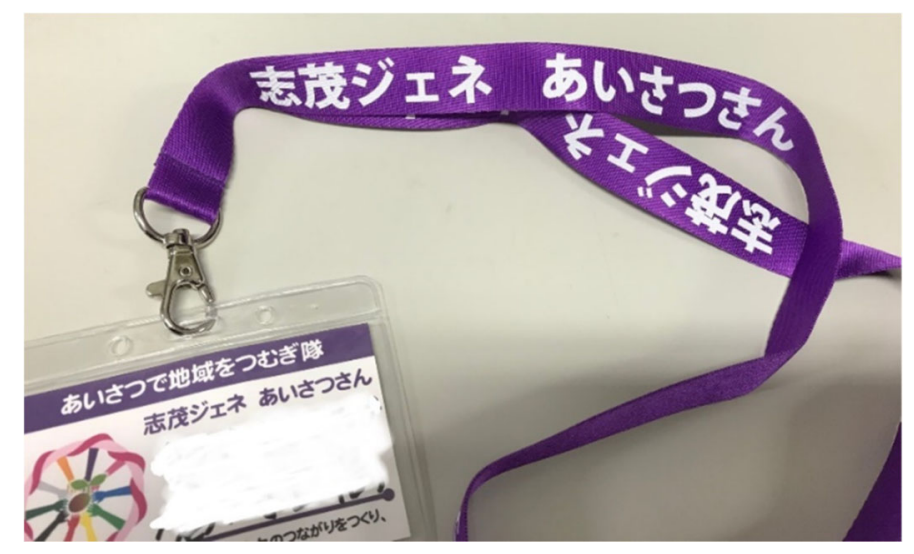

写真 3 「あいさつさん」が活動時に着用するネックストラップ

【川崎市多摩区中野島地区】

- 多摩区では平成 28 年度に募集した標語とロゴマークを記した横断幕を作成し、駅前、各学校 の校門に掲示した（写真 4 ）。

- 多世代住民間で挨拶をしあうことの意義を伝えるミニ講座 (15 分程度) のカリキュラムを作成 し、モデル地区の町会の定例会（多摩区 1 自治会）にてミニ講座を試行した。

- 協議会メンバーがモデル地区の小学校に出向き、児童に対し挨拶の重要性について講話をした。

- モデル地区の小中学校の入学式にて、新入生ならびにその保護者に対し挨拶運動を実施した。

- 地域イベントである中野島音楽祭（毎年7月開催）、その他の地域イベント（例 : 多摩川住宅 避難訓練（平成 29 年年9月）にて、同ミ二講座の内容をパンフレット形式にした資料とリング （挨拶運動参加者であることを見える化したリング）、28年度に募集したロゴマークを使って 作成した缶バッジを配布した（写真 4)。

- 町会・老人会で組織される地域の見守り隊に本プロジェクトのベストを配布し、着用して活 動してもらっている。

・ 中野島つながり愛フォーラムの様子についてまとめたニュースレター平成30年4月に発行し、中野島 町会の回覧板と一緒に地域住民に600部配布した。 


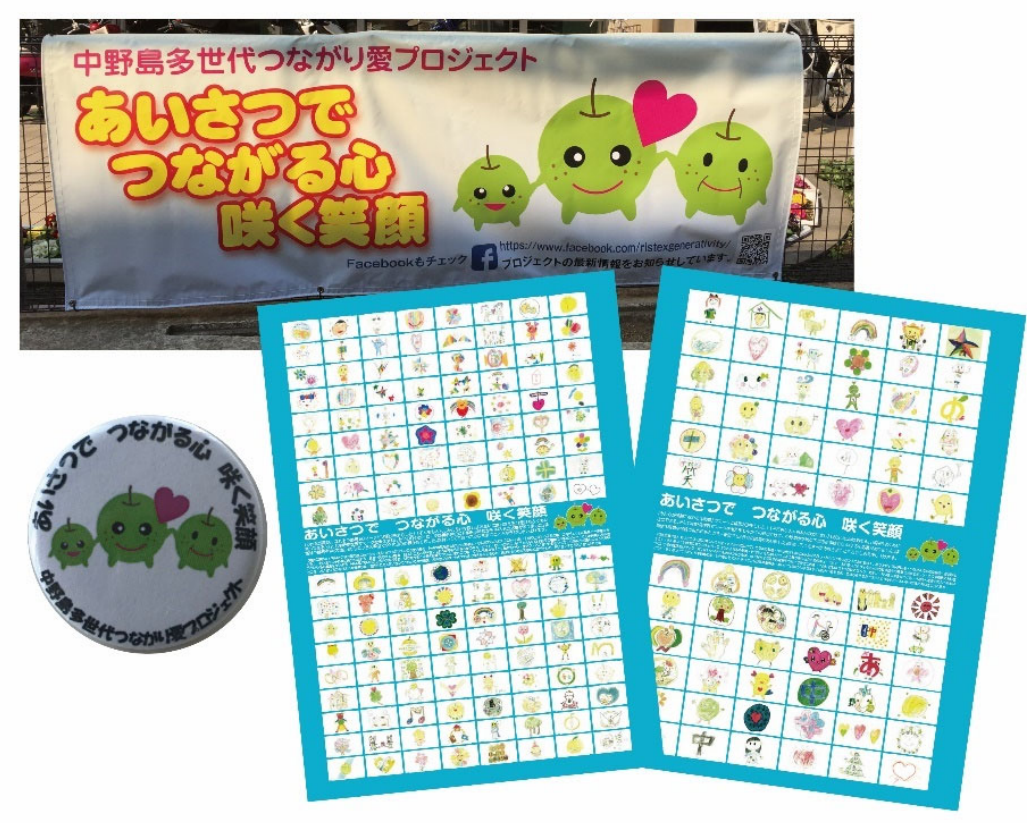

写真 4 中野島地区での挨拶運動やキャンペーンのグッズ

\section{2-3-2．多世代交流を基盤とした多世代住民間互助の確立}

○達成目標 $2:$ 多世代交流を基盤とした多世代住民間互助の確立

目的 : 多世代交流プログラムを基盤とした互助の仕組みづくりにより、1）日常生活の延長線上 での気軽な手段的相互支援の授受促進、および、2）地域の多世代住民間での交流機会の 増加によるジェネラティビティの醸成がなされることを目的とした。

実施内容 :

【2 地区共通の実施内容】

- 多世代交流プログラムの企画と運営、および交流を基盤とした互助を促す「まち・人・くら しプロモーター」(通称：まちプロ）を養成する研修プログラムを開発し、両地区で実施した。 研修プログラムは、交流の場と互助の仕組みの運用に必要な知識を身に付ける講義形式の講 習会と実地研修から構成される。

- 民間のシステム（(株）AsMamaの「子育てシェア」）を基盤に、多世代間で支援の受け手と 担い手をマッチングするウェブシステム「よりあい」を開発した。さらに、モデル地区での 試行を通じて、当該システムの社会実装に必要な要件や課題等を抽出した。

- 上記「よりあい」の試行において、特に高齢者の「よりあい」利用に必要なデバイスの普及 率や、デバイスの限定的な利用実態など様々な課題があがったため、両モデル地区では実装 に至らなかった。そこで、平成 29 年度末からは、両地区で多世代交流の拠点を基盤とした、 「よりあい」に限定しない当事者同士の助け合いに関する仕掛けや仕組みを開発していくこ ととなった。

- 日常生活場面における地域住民の支援ニーズをボトムアップに抽出し、潜在的な担い手を発 
掘するツールとして、住民参加型のワークショップ「お互いさまゲーム」*（写真 5）を開発 し、異なる世代の地域住民が集まる交流サロンや地域の会議体で試行した（平成 30 年 5 月ま でに 30 代〜80 代の男女約 150 名が参加)。

-「お互いさまゲーム」を通じ、異なる世代の住民間における「助け合い」を擬似的に体験す る**ことで、参加した住民が自らの支援ニーズを認識すると共に、当該ニーズを周囲の人々 に頼り、頼られながら解決するというイメージを持ちやすくなり、ひいては実生活場面での 支援のやり取りへと結びつくことを目指した。

*「お互いさまゲーム」開発の背景 : 住民間互助を実現する上での課題として、多世代交流プロ グラムの参加者の多くが以下の4点を指摘した ; (1)住民同士で「助け合う」ことのイメージがつき にくい、(2)顔見知りに支援を求めることに抵抗感がある、(3)支援ニーズが「頼まないと生きてい けない」わけではない内容であるからこそ、本人から積極的に頼みづらい、(4)自分が抱える支援 ニーズが何かを具体的にイメージできない。「お互いさまゲーム」は、これらの課題克服の方法の 一つとして開発された。

**「お互いさまゲーム」の基本的な手順 :「お互いさまゲーム」は6〜8名程度のグループで実施 し、ファシリテーター1名が進行を務める。ゲームは、以下3つの手順から構成される; (1)参加者 が自身の体験に基づいて「日常生活の中で、誰かの手を借りたいと思うこと」を指定のカード（付 箋でも可、1枚につき1つの困りごとを記入）に書き出す、(2)記入したカード（付箋）を提示しな がら、内容の詳細を他の参加者と共有する、(3)挙げられた困りごとについて、担い手・受け手双 方の視点から、参加者間で具体的な支援の手立てを話し合う。

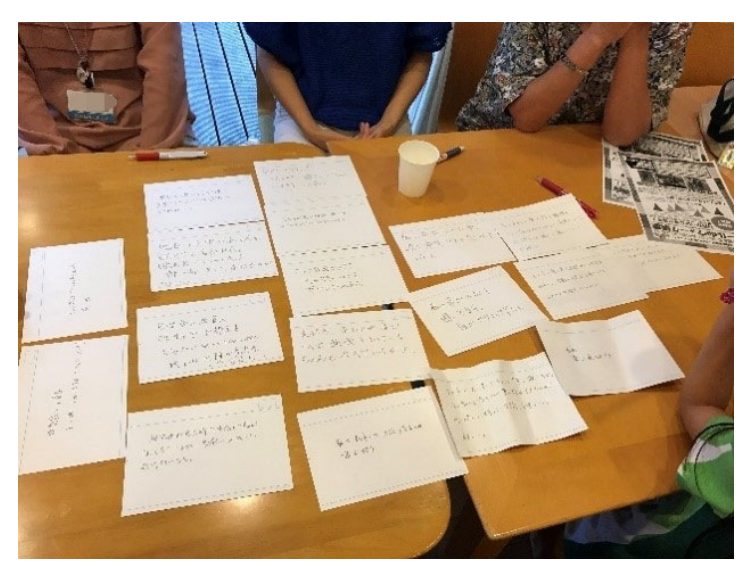

写真 5 お互いさまゲームで困り事を提示

【北区での実施内容】

- 北区では「まち・人・くらしプロモーター」（通称：まちプロ）を養成するため、平成 28 年度に 第一期、平成 29 年度に第二期の研修を実施した。

- 世代を超えた互助の基盤となる多世代交流の機会を広く地域住民に提供するため、まちプロの 自主企画による各種イベントの開催（各町会でのまち歩きイベントなど、計3回開催）と、サロ ンの開設・運用（2ケ所）を行った。

- 平成30年3月には、志茂ジェネ協議会（後述）主催の大規模な多世代交流イベントとして、「第 
一回志茂ジェネまつり〜多世代（みんな）で楽しむひなまつり〜」を開催し、協議会に参画す る各地域活動団体のメンバーやまちプロ、その他地域の自主グループが協働して企画・運営を 行った。

- 平成29年度より、地域の子育て支援団体「ほっこり〜のプラス」が運営する子育てサロンにて、 多世代交流サロン「よりあい俱楽部 〜かよう広場〜」を開催した（毎週火曜日開催）。平成30 年度からは「多世代交流day」と名称を変更し、「ほっこり〜のプラス」の一事業として当該サ ロンを継続的に運営している。まちプロは引き続き運営支援に関わり、子育て世代を中心とし た多世代交流を推進している。

-「よりあい」の普及に向けて、上記「よりあい俱楽部 〜かよう広場〜」でPRを行うと共に、 高齢者を対象としたスマートフォン講座を1回開催した。

- 平成30年6月より、北区社会福祉協議会の運営する地域小規模活動拠点（正式名称：北社協志 茂地区小地域活動拠点）にて、新たな多世代交流の拠点「よりあい俱楽部」を開設した（写真 $6)$ 。毎月第 1 ・第 3 木矅日の 10 時〜 12 時に、講座の開催とカフェの運営を行なっている。運営の 担い手はまちプロであり、高齢者を主なターゲットとした多世代交流を推進している (写真7)。
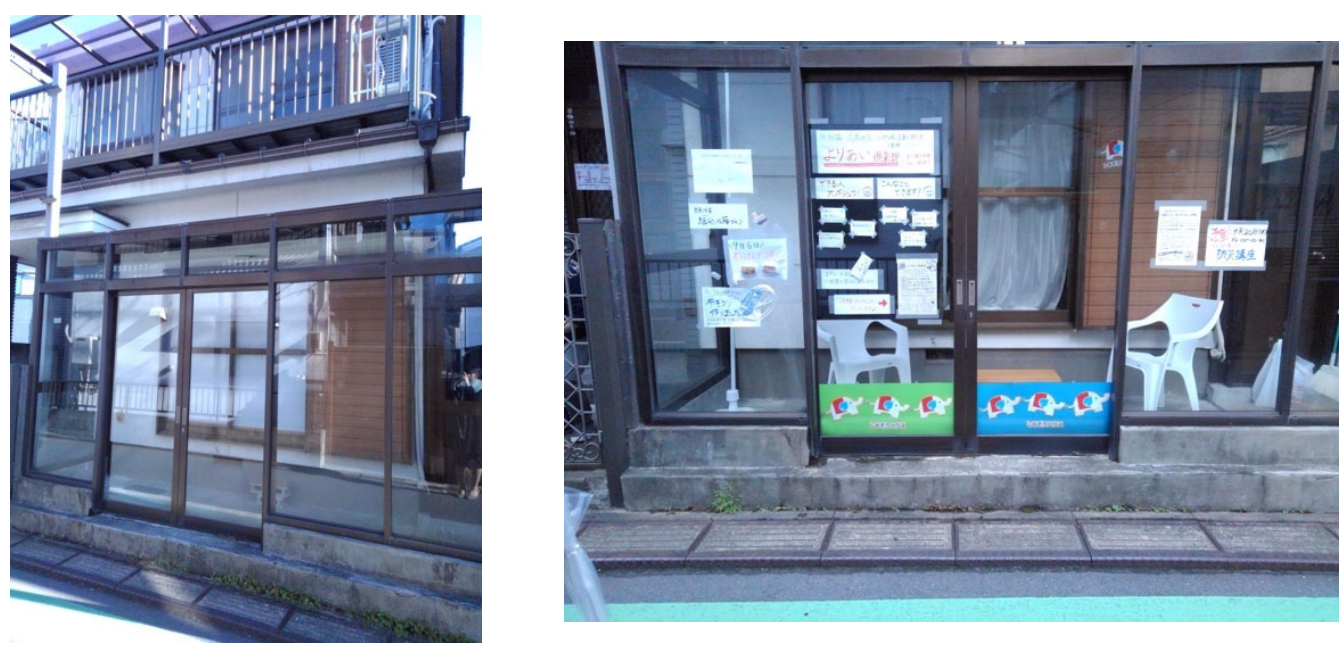

写真 6 北社協志茂地区小地域活動拠点の外観
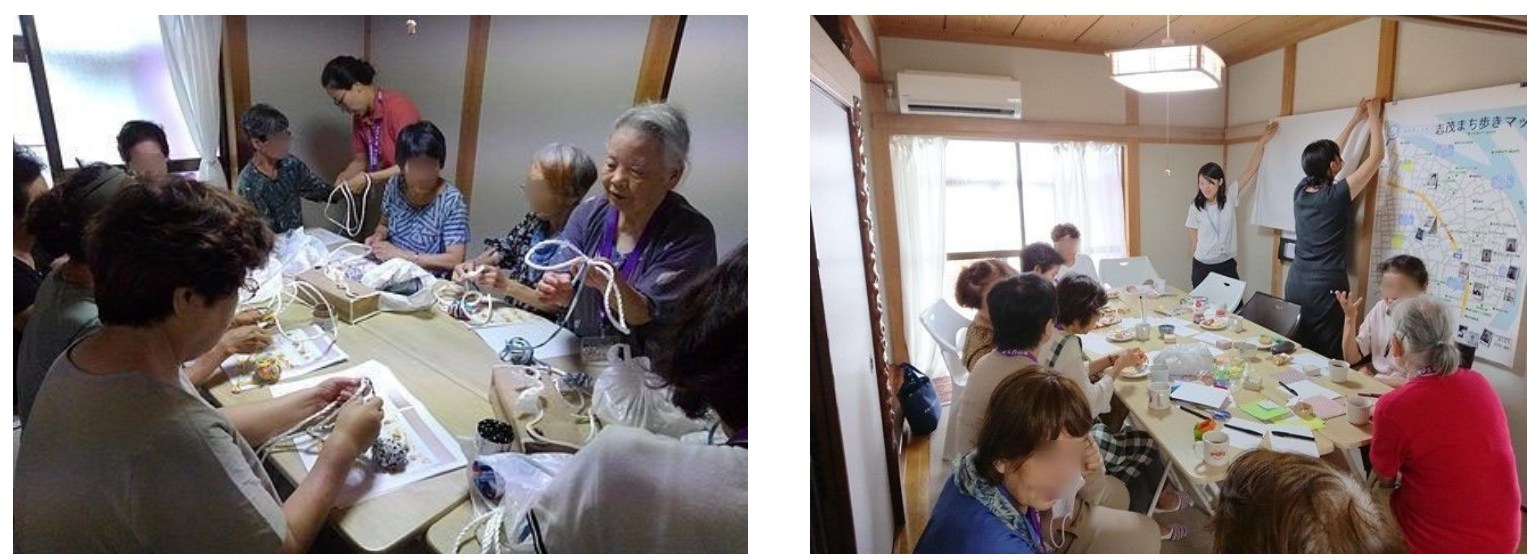

写真 7 「よりあい俱楽部」の活動風景（左：裁縫講座、右：お互いさまゲーム） 
- なお、「北社協志茂地区小地域活動拠点」は、社会福祉協議会が志茂ジェ市協議会と行政の支援 のもと、開設した。志茂ジェネ協議会での検討を通じて、同拠点の愛称を「しもぞう八ウス」 と定めた。

- 上記「しもぞう八ウス」を地域の助け合いの拠点とすべく、「よりあい俱楽部」にて互助の仕組 みづくりを推進している。第一の方法として、まちプロが「よりあい俱楽部」内で対応可能な 支援項目（それぞれのまちプロの特技など）を建物の外から見える掲示板で提示している（写 真 8)。第二の方法として、「よりあい俱楽部」の中で身近な地域の助け合いにつながる講座や イベントを企画し、参加者同士の交流の中で支援ニーズを引き出すと共に、支援の担い手が拠 点に集うような働きかけをまちプロが主導して行っている。例えば、裁縫講座をきっかけに、 縫い物や編み物が得意な（裁縫関係の支援の担い手となる）地域住民がまちプロを中心として

「しもぞう八ウス」に継続的に集まっている。今後は、こうした緩やかな住民グループが、ボ タン付けや裾上げといった裁縫関係の困りごとの受け典として機能することを目指している

(図 2上部)。また、「よりあい俱楽部」の中で上記のお互いさまゲームを活用することにより、 参加者の抱えるニーズを浮き彫りとし、それらを具体的な支援に結びつける取り組みも並行し て実施中である。ゲームの結果、抽出された支援ニーズが拠点内で対応可能である場合には、 その内容に応じて「しもぞう八ウス」の担い手グループ（先述の裁縫を得意とする、緩やかな 住民グループなど）へつなぐか、もしくはその場で参加者同士のマッチングを行う。拠点内で の対応が難しい場合には、地域資源（志茂ジェネ協議会でつながりのある他の団体や、専門職 など）について情報提供を行ったり、本人の希望に応じて当該ニーズを掲示板に掲載し、拠点 外の担い手を募集する取り組みも計画中である（図 2 下部）。

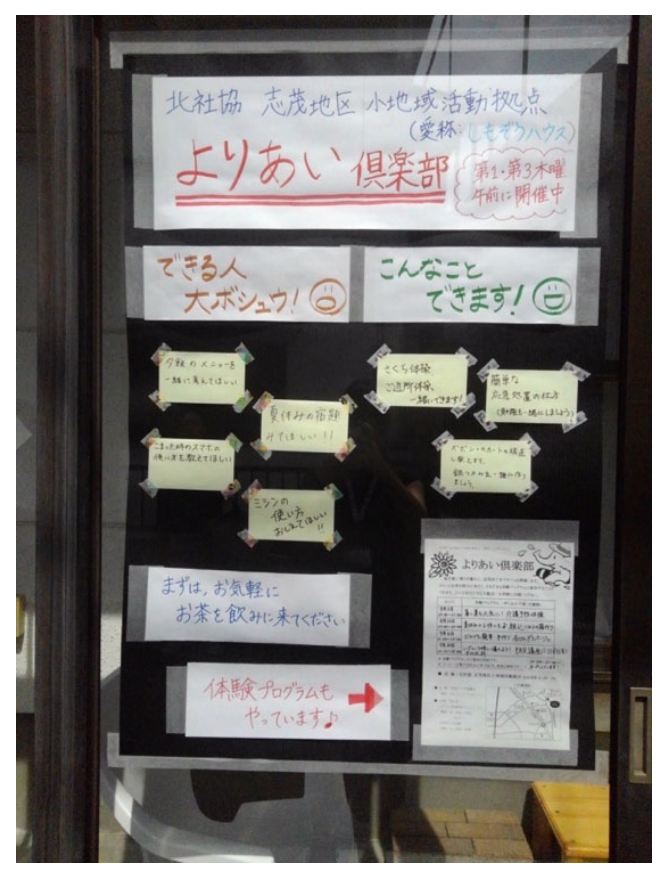

写真 8 まちプロが対応可能な支援項目を掲示板で提示 


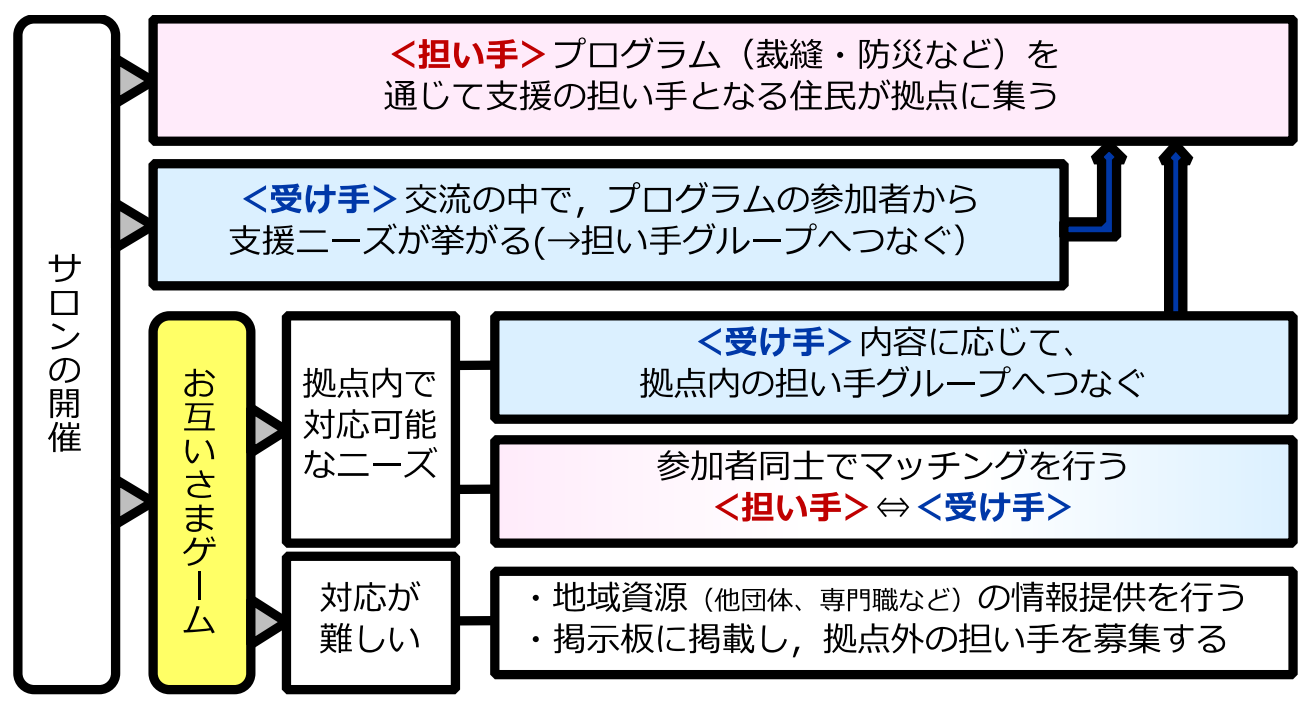

図 2 「よりあい俱楽部」における互助の仕組みづくり

-まちプロは、地域包括支援センターと北区社会福祉協議会のそれぞれに配置された生活支援コ 一ディネーター（地域包括支援センターの生活支援コーディネーターは見守りコーディネータ 一を兼務しており、本プロジェクトで立ち上げた協議会の自主化後に、事務局の中核的機能を 担う）による共同支援のもと、上記の交流の場や互助の仕組みを運営する形態で、現在体制を 整えつつある。

\section{【神奈川県川崎市多摩区】}

- 多摩区では平成 28 年度、 29 年度、30年度の 3 期で、まちプロを養成し、合計 18 名が研修を修 了した。

- 平成29年年2月に、協議会メンバーが中心となり、外遊びと食を通した多世代交流イベント 「中野島あそび愛交流会」を実施した。本イベントには約80名の地域住民が集い、多世代で の交流を深めた。平成 29 年 6 月より平成30年10月まで、毎月第一水曜日に高齢者住宅である 上布田つどいの家《運営法人は（株）生活科学運営》が運営する地域交流室にて多世代交流 カフェ（上布田カフェ）を実施した。

- 平成30年3月から第二・第四金曜日に、中野島公民館にて「中野島ファミリーカフェ」を実施 している（写真 9）。第二金曜日は外部講師を招いてストレッチ体操や笑いヨガなどのプログ ラムを行い、プログラムの後に参加者同士が交流する時間を設け、まちプロを介した交流や 参加者同士の交流が行われている。第四金曜日は、カフェの中で互助の発生を促すため、ま ちプロの特技を活かしたブースを複数設置し、参加者同士やまちプロによる「お助け」が発 生するよう運営している。 

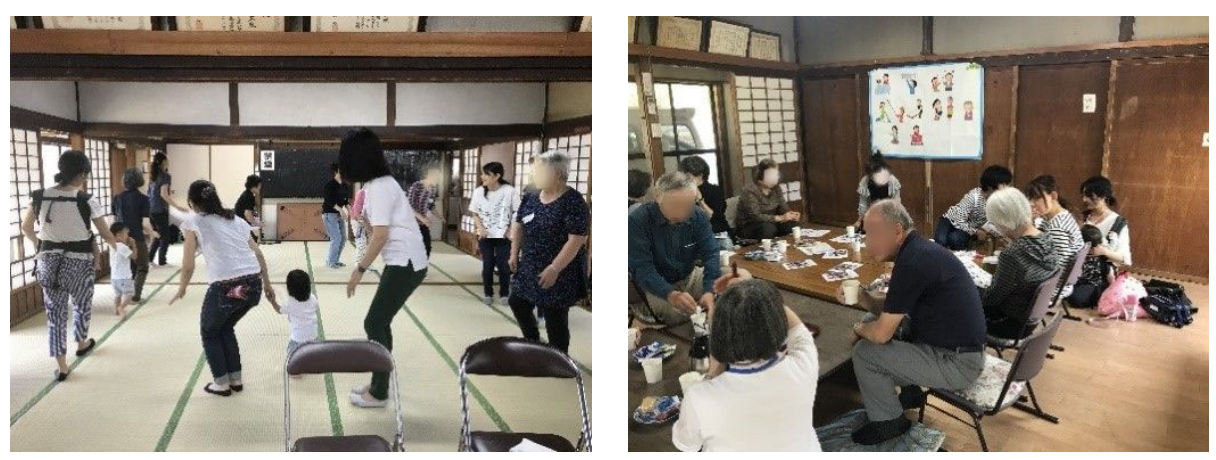

写真 9 中野島ファミリーカフェの交流プログラムの様子

・ 各まちプロの特技を活かしつつ、カフェ内で完結する互助を推進している。

- 平成29年12月より月 2 回ポールウォーキングの活動を実施している。ポールウォーキングは、 9月から全4回実施した、「ポールdeウォーク講座」の事後活動として実施しており、毎回10か ら15名程度の参加がある。

\section{2-3-3. 多様な背景をもつ子どもへの学習・居場所支援の充実}

○達成目標 3 [生活基盤、学習支援、居場所支援] : 多様な背景をもつ子どもへの学習・居場所支 援による生活基盤の改善

目的: 平成 27 年度に実施した先行研究レビューおよび事例調査を踏まえ設定目標を、多様な背 景をもつ子どもに対する学習支援および居場所支援により生活困穿家庭を含む多様な背景 を持つ家庭を多世代の住民間で緩やかに支援する生活支援サービス提供モデルおよび多世 代交流プログラムの開発へ変更した。具体的には、多世代交流の場とそこで生まれる互助

（達成目標 2）に、多様な背景をもつ子どもとその保護者も自然に参画できることを目指 す。

実施内容：

- 平成 27 年度に、子ども食堂の実態を把握するために、全国の優良事例 11 件を対象とした文 献レビューおよびインタビュー調査を実施した。

【北区での実施内容】

- 北区社会福祉協議会が北区内の学習・居場所支援を行う各種団体やNPO を対象に開催したネ ットワーク会議（3 回）に参加し、当該団体・NPO との横のつながりを構築すると共に、北区 での取り組みの現状について情報共有を行った。

- ほっこり〜の志茂店で月一回開催中の子ども食堂において、まちプロがスタッフとして参加 し、多世代交流の場で培ったノウハウをもとに運営の補助を行った。

\section{2-3-4. 多世代協議会の立ち上げと運営}

○達成目標 1〜3 に向けて：協議会の継続体制と地域での役割の明確化

目的：生活支援体制整備事業では地域の互助活動を支援・推進する協議体の設置が定められてい 
る。本プロジェクトの協議会は当該事業の第 2 層の協議体（中学校圈域レベルの協議体） と位置づけて行政施策として継続できる見通しがたった。北区では、地域包括支援センタ 一に配置された生活支援コーディネーターを中心に社会福祉協議会と自治体が事務局機能 を担うこととなった。多摩区では、自治体（地域見守り支援センター）の中野島地区担当 保健師を中核に自治体・地域包括支援センター・地区社会福祉協議会が事務局機能を担う こととなった。協議会の役割は、地域で多世代共生や互助に資する活動に取り組みたい 人・団体が必要な資源を得ることを支援する事とした。最終年度は、この第 2 層協議会が 地域の多世代住民間での互助を創出する多様な活動を支援する団体として実質的に機能し ていく体制を確立することを目指す。

実施項目：

【北区での実施内容】

- 平成 28 年 2 月より、志茂地区を支える地域活動団体の代表者や専門職、行政職員、企業、研 究者が参画する協議会（通称：志茂ジェネ協議会）を発足し、原則月一回のペースで開催し た（平成 30 年 9 月末までに計 28 回開催）（写真 10）。

- 平成 30 年 9 月現在における「志茂ジェネ協議会」の構成メンバーは以下の通りである; 町 会・自治会、青少年地区委員会、民生委員児童委員協議会、介護予防リーダーの会、志茂子 ども交流館 (児童館)、シニアクラブ、北区シルバー人材センター、子ども家庭支援センター、 水辺の苑高齢者あんしんセンター（地域包括支援センター）、志茂地域振興室、北区社会福祉 協議会、スクールコーディネーター、株式会社ほっこり〜のプラス、株式会社 AsMama、北 区担当者（高齢福祉、子育て、教育など、各分野から代表者を選定）。

- 北区役所、北区社会福祉協議会、ならびに地域包括支援センターと共に、北区における今後 の生活支援体制整備事業の方針等を確認しながら、プロジェクト終了後の協議会のあり方を 明確化し、プロジェクト終了後も協議会を継続することが決定した。また、志茂ジェネ協議 会の参加メンバーからも、プロジェクト終了後の協議会継続について合意を得た。

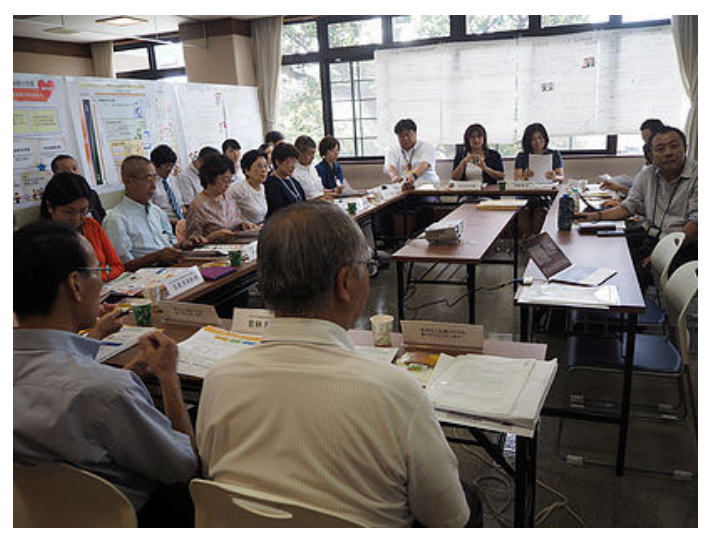

写真 10 志茂ジェネ協議会の様子

\section{【川崎市多摩区】}

・ 多摩区では平成27年3月〜平成30年9月末までに20回の協議会を実施した。

- 平成30年2月24日、プロジェクトの啓発とさらなる協力者を募るため「中野島多世代つなが り愛フォーラム」（写真 11）を開催した。このフォーラムをきっかけに地域の関係団体に協 議会参加を呼びかけた結果、新たに2団体（カリタス学園、中野島住宅自治会）が参画し 
た。プロジェクト開始時に参画した17団体も継続して参加することとなった。

- 協議会は今後年4回開催する予定であり、中野島つながり愛フォーラムも年1回実施する予定 である。

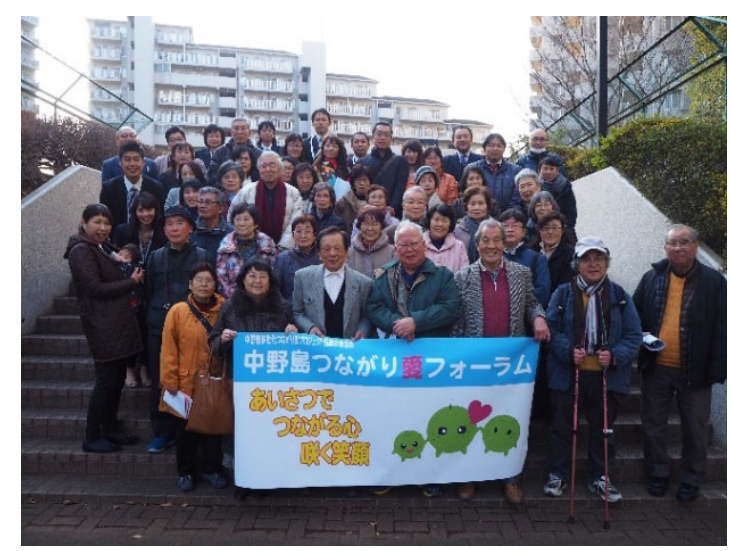

写真 11 中野島つながり愛フォーラム 


\section{3. 研究開発結果・成果}

\section{3-1. プロジェクトの目標達成状況及び結論}

本プロジェクトでは、最終ビジョンである「子どもの健やかな成長の喜びを全ての世代が共有 できるまちづくり」に向けて；1）多世代挨拶運動を通した世代間の緩やかなサポートネットワー クの形成による世代間の信頼の高まり、2）多世代交流を基盤とした多世代住民間の互助の確立、 および 3) 多世代交流の場等で多様な背景をもつ子どもへの学習・居場所支援の確立を目指した。

○達成目標 1 多世代挨拶運動を通した世代間の緩やかなサポートネットワークの形成による世 代間の信頼の高まり

(1) 世代間の信頼の高まりについて

両モデル地区にて、地域の小・中学生が作成したロゴマークを活用したグッズの配布、ジェネ ラティビティと挨拶の意義を伝えるミニ講座の実施、および多世代挨拶運動（特に北区における 「あいさつさん」の活動）を行った。これらの取り組みを通して、世代間の緩やかなサポートネ ットワークの形成による世代間の信頼の高まりを目指した。

これらの普及啓発活動が世代間の信頼感の高まりに寄与したから゙うかについては、平成 30 年 10 月に実施する一般住民調査で検証予定である（ベースライン調査は平成 28 年に実施済みであ る)。具体的には、質問紙調査により以下の（1)～(5)を尋ねる；(1)本プロジェクトで開発したロゴマ ークや標語、プロジェクト名（志茂ジェネと中野島つながり愛プロジェクト）に関する認知度、 (2)多世代住民間での信頼感、(3)地域への愛着感、(4)多世代住民間での手段的・情緒的支援の授受、 および(5)ジェネラティビティ。当該調査により、(2)〜(5)がベースライン調査時よりどの程度高ま ったかを(1)との関連から検証する。

(2) 多世代共創社会をつくる地域活動の基盤となる緩やかなサポートネットワークの形成

本プロジェクトにおける協議会は、単に地域課題を議論するだけの場ではなく、プロジェクト の最終ビジョンである「子どもの健やかな成長の喜びを全ての世代が共有できるまち」を実現す るために、各モデル地区に適した取り組みの企画・開発およびその実装方法を検討する場として 位置付けられている。例えば、北区の「あいさつさん」の取り組みは、協議会および作業部会の 議論の中で、協議会参画団体のメンバー（代表以外の役員や、一般会員など）が関わりやすく、 かつ日常的に子どもたちへ働きかけることができる活動として開発・実装された。同様に、多世 代共生ならびに多世代共助の重要性と、志茂ジェネ協議会の活動を地域に広く普及啓発するため に、「第 1 回志茂ジェネまつり 〜多世代（みんな）で楽しむひなまつり〜」をはじめとする、様々 な協議会主催のイベントが企画・開催された。それぞれの取り組みやイベントの検討に際しては、 本プロジェクトの目標をロジックモデルに基づき確認しながら進めることを意識した。また、協 議会主催のイベントでは協議会のメンバーが自分の所属団体および関連団体に、協議会および各 イベントのビジョンを説明したうえで協力を求めた。

このような協議会運営を通して、協議会メンバーの間で本プロジェクトのビジョンに対して共 感を深めたと考える。また、両モデル地区では以下の 2 種の横断的連携が達成されたことから、 緩やかなサポートネットワークの形成にも至った ; 1)異なる世代を代表する組織・団体間での連 携、および(2)町会・自治会といった地縁組織・団体と、企業やボランティアグループ・NPO とい った好縁組織・団体間の連携。 
例えば、北区志茂地区では志茂ジェネ協議会を契機として、子ども・子育て支援を主な業務や 活動内容に据える機関・団体（志茂子ども交流館や、株式会社ほっこり〜のプラス、青少年地区 委員会）と、高齢者支援を主たる業務とする地域包括支援センターとの間で協働事業が起きてい る。その一例として、志茂子ども交流館が施設を利用する子どもたちに、有事の際に助けを求め ることができる場所として地域包括支援センターを紹介することがあった。この地域包括支援セ ンターが小学校の通学路の途中に位置していることもあり、先述の「あいさつさん」の活動とあ わせて職員が子どもたちの見守りに取り組んだ結果、従来よりも身近な場所として当該センター を捉え、実際に立ち寄る子どもの姿も見られたという。また、同じく志茂子ども交流館が地域包 括支援センターにハロウィンイベントへの参画を呼びかけたことにより、地域の高齢者が初めて 同イベントに参加した。さらに、青少年地区委員会は志茂ジェネを通して社会福祉協議会や保護 者会等と繋がり、新たな活動を展開することができたという。

3. 世代を超えた横断的連携によるコーディネート機能の強化

本プロジェクトを通じた波及効果として、志茂ジェネ協議会の事務局を担う第 2 層生活支援コ ーディネーターの強化が挙げられる。当事者への聞き取り調查の結果、志茂ジェネに関わる以前 は、生活支援コーディネーターに求められている役割や具体的な業務の進め方に迷う場面も多か ったが、志茂ジェネ協議会の運営やまちプロの支援を通して、自身の役割や業務に対する理解が 進んだことが聞き取り調査で指摘された。例えば、前述の子ども交流館から依頼を受けた八ロウ インイベントでは、同イベントに参加した高齢者からは子どもと交流できて「楽しかった」とい う声が、非参加者からは「やりたかった」「声をかけて欲しかった」という意見が出たという。こ の意見を受け、地域包括支援センターのコーディネーターは当該センターで全て対応する必要は なく「(住民に) 頼めばいいんだ」という気づきを得たという。また、訪問型傾聴ボランティア事 業を見直したい社会福祉協議会と新たな活動の場を求める傾聴ボランティア団体をつなぎ、新た な訪問事業を展開寸る準備を進めている。全国には多数のコーディネーターが配置されているが、 役割が明確でないといった共通の課題を有している。本プロジェクトを通じて、コーディネータ 一が団体間または団体と人を「繋ぐ」ことにより地域でサポートネットワークを形成する、とい ったコーディネーターの役割や業務手法も提示できたと考える。

さらに、地域包括に配置されたコーディネーターが子ども・子育て支援団体（北区では子ども 交流館、ほっこり〜の、および青少年地区委員会 ; 多摩区では小学校や保育園）と連携し始めた ことにより、高齢者を主な担い手とした多世代共創社会に繋がる活動が活発化することが期待さ れる。地域包括は高齢者の在宅生活を支える地域のネットワークづくりの中核的な機関として位 置付けられている。また、先行研究により社会参加・社会貢献活動が高齢者の心身の健康維持 ・ 増進に有効であることが認められていることから、地域包括は高齢者を介護予防として社会参加・ 社会貢献活動へ繋げることも求められている。

両モデル地区の地域包括が、子ども・子育て支援団体と協働したことにより、地域包括が関与 する多様な地域活動に「多世代」の視点を取り入れることの利点を認識できたことが聞き取り調 査で示された。特に保護者を含めた 3 世代交流の良さが指摘された。様々な活動に 3 世代交流を 取り入れることで、自然な交流が発生しや寸くなること、高齢者が役割を持てること、自然な交 流と役割獲得の相乗効果として高齢者が、より楽しめることが指摘された。

今後も地域包括支援センターと子ども・子育て支援団体との横断的連携が発展すると思われる。 つまり、両モデル地区では、今後も 3 世代交流が進むことから、介護予防活動を通して高齢者の ジェネラティビティが高まることが期待できる。一方、若年世代の間では、高齢者への信頼感や 親しみが高まり、ひいては高齢者に対する見守り意識も向上すると考える。 
4. サポートネットワークを基盤とした「あいさつさん」の取り組みによる世代間の信頼の高ま り

地域で形成されたサポートネットワークを基盤とすることで、多世代共創の取り組みの継続と 普及が可能となることが分かった。志茂ジェネ協議会の活動を通して醸成された団体間のサポー トネットワークは、志茂地区での「あいさつさん」の継続的な取り組みの基礎ともなった。「あい さつさん」の取組には、主要な地域活動団体 (町会・自治会、青少年地区委員会、民生委員児童委 員協議会）の会員を主に 110 名が取り組んでいる。協議会はプロジェクト終了後も各団体で「あ いさつさん」の取り組みを推進・支援することに賛同している。特に、子どもを対象とした大規 模なイベントを頻回に開催する青少年地区委員会のメンバーからは、本プロジェクトおよび「あ いさつさん」が目指すビジョンに共感すると考え、団体の活動にも取り入れていきたいと考えて いることが聞き取り調査でも指摘された。

研究班が平成 28 年度に各モデル地区と非介入地区の小中学校の児童生徒（小学 4 年生〜中学 2 年生) 2,580 名を対象に実施した調査でも、子どもが挨拶をする頻度と教職員や地域住民から挨拶 をされる頻度に相関があること、挨拶をしあう頻度の高い子どもは地域への愛着が高い、他者へ の援助行動をとりや寸いといった結果が明らかになった。したがって地域の主要団体と共に、「あ いさつさん」を通して子どもたちへ継続的に働きかけ続けることで中期的には世代間の信頼が形 成され、長期的には最終ビジョンである「子どもの健やかな成長の喜びを全ての世代が共有でき るまち」も達成できると考える。

5. まちプロの活動とネットワークの形成と世代間の信頼の高まり

多世代で構成されるまちプロは、その関係がサポートネットワークの基盤となっている。交流 プログラムの企画や運営において多くの時間を共有する中で、子育て世代のまちプロは高齢世代 のまちプロから、自身の子どもへの良い影響を受けているだけでなく、自身のストレスも軽減さ れているという。例えば、家庭では子供のしつけのために子供を叱る場面が多いが、高齢者のま ちプロはちょっとしたことで子供や子育てをしている自分を誉めてくれる。また、子育て世代の 集まりでは他の子供と比べてしまいがちだが、まちプロではそのようなことがないため、まちプ ロでの活動の時間を心地よいと感じている。さらに、仕事の体験談を聞いたりすることで、自身 の仕事へのビジョンや健康意識の高まりが得られたことを聞き取り調査であげている。一方、高 齢者世代のまちプロも、子育て世代のまちプロと交流することによって、自分が必要とされてい ることを感じている、将来の姿を見せることができているのではないかと思うという声があった。 こうしたお互いをリスペクトし合える関係がまちプロの間には生まれている。参加者同士では、 このようなレベルの信頼関係は十分には生まれていないが、まちプロと参加者同士での信頼関係 は出来つつあり、また参加者同士にといても、まちプロがそうであったように、交流を重ね、同 じ時間を過ごすことによって信頼関係が構築されることが期待される。世代間の交流のうながし や信頼関係の構築には、つながりから信頼への変化を体感しているモデルとしても、まちプロの 存在は重要である。

多摩区では平成 30 年度からまちプロが協議会のメンバーとして会議に参加することになった。 地域の既存団体と、まちプロのような新しい住民組織が融合することは、ネットワークの形成に とっては重要であった。まちプロは協議会や協議会主催のフォーラムに参加することによって、 より梁く地域のニーズや資源を把握することができるようになった。また、聞き取り調査では、

「まちのことを考えるようになった、知りたいと思うようになった」という意見や、「知らない人 にも挨拶をするようになった。気分がよくなることを知った」という意見があげられた。地域で のネットワークが広がることによって、既存の組織や住民に対する信頼が増していることが同え る。既存組織のメンバーからも、普段接寸ることがない若い世代のまちプロと接することによっ 
て、地域に眠っている力の存在を感じ、肯定的に評価する声があった。それまで接点がなかった 世代同士でも、協議会という場を通して、同じ目標を十分な時間をかけて共有することが出来れ ば、信頼関係が構築できることが示された。

\section{【結論】}

- 両モデル地区にて普及啓発活動および多世代あいさつ運動を実施した。その効果としての世 代間の信頼の高まりについては、現在実施中の住民調查により検証する。

・協議会では、プロジェクトの最終ビジョンである「子どもの健やかな成長の喜びを全ての世 代が共有できるまち」を実現するために、各モデル地区に適した取り組みの企画・開発およ びその実装方法を検討した。また、協議会主催のイベントを実施した。イベント開催に際し て、協議会のメンバーが自分の所属団体および関連団体に、協議会および各イベントのビジ ヨンを説明したうえで協力を求めた。このような協議会運営を通して、協議会メンバーの間 で本プロジェクトのビジョンに対して共感を深めたと考える。また、両モデル地区では異世 代を代表する組織・団体間での連携、および地縁組織・団体と NPO・ボランティアといった 好縁組織・団体間の連携が達成されたことから、緩やかなサポートネットワークの形成にも 至った。

-「「いさつさん」の取り組みには、協議会構成団体の会員を主に 110 名が参加している。地 域で形成されたポートネットワークを基盤とすることで、多世代共創の取り組みの継続と普 及が可能となることが分かった。すなわち、北区志茂地区では、協議会を基盤としたサポー トネットワークにより、「あいさつさん」が継続的に取り組まれている。地域の子どもたちへ 継続的に働きかけ続けることで中期的には世代間の信頼が形成され、長期的には最終ビジョ ンである「子どもの健やかな成長の喜びを全ての世代が共有できるまちも達成できると考え る。

- モデル地区内の生活支援体制整備事業の第 2 層生活支援コーディネーターは、協議会運営と それにより構築されたネットワークとの協働事業から、コーディネーターとしての役割を認 識できることができた。地域資源（地域の多様な団体や地域人材）同士を調整・繋ぐ業務を 実質的に行い始めた。

- 多世代で構成されたまちプロの間では、交流の場運営という多世代共創を通してお互いをリ スペクトし合える信頼関係生まれている。

○達成目標 2 : 多世代交流を基盤とした多世代住民間互助の確立

1.「よりあい」の実装から明らかになった ICT を活用した互助の課題とお互い様ゲームの開発

（株）AsMama と共に「よりあい」を開発し、平成 28 年度より「よりあい」の実装を目指し た。両モデル地区にてまちプロが中心となり多世代交流カフェ（多摩区は上布田カフェ、北区は ほっこり〜のでのよりあい俱楽部）と多様な多世代交流イベントを開催し、その中で多世代住民 同士の交流促進と「よりあい」への登録と利用を勧奨することにより、「よりあい」を介した多世 代型互助モデルを促進した。

一連のプロセスから以下の 7 つの「りあい」普及および住民間互助促進における課題が明ら かになった ; (1)高齢者のスマートフォン利用率の低さ、(2)高齢者のスマートフォン利用方法が限 定的であること、(3ITC リテラシーの対応、(4)「よりあい」インターフェースが子育て世代にと ってもわかりにくいといった問題、(5) 支援ニーズが顕在化しない、6顕在化した支援ニーズも「頼 まないと生きていけない」わけではない内容であるからこそ、本人から頼みづらい、(7)近隣住民 
に支援を求めることへの抵抗感。これらの課題は特に高齢者で顕著であった。

そこで研究班は、被援助志向に関寸る課題（(5)～(7)）を解決寸るために、多世代交流プログラ ムの中で交流を深めると同時に支援ニーズを顕在化させる「お互いさまゲーム」を開発し、多世 代交流プログラムの中で試行した。研究班は、自らの支援ニーズを考えて表現することで支援ニ 一ズに気づく、他者の支援ニーズを知ることで自分の支援ニーズに気づくことを期待した。また、 多世代交流プログラム参加者同士で支援ニーズを共有することで、参加者同士での助け合うきっ かけとなることも目指した。

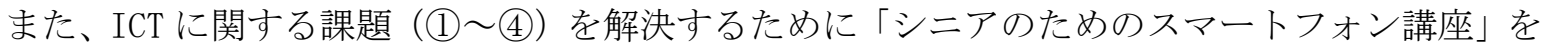
開催した。子育て支援をしているほっこり〜の志茂店を会場に開催したことから、よりあい使用 時に世代を越えた互助が展開されることを見越して、近隣在住の子育て世代 2 名にスマホ講座の アシスタントとして参加してもらった。しかし、以下の課題から「よりあい」登録と利用には至 らなかった； (1)iPhone を使用すると銘打って講座を開催したものの、受講者の多くは指定以外の デバイスを使用しているものが参加した。また、自身のスマートフォンが何かを十分に理解して いなかった。(2)講座で使い方が理解できても一人では操作できないという人も多くいた。(3)スマ 一トフォンの基本的な操作を習得できた人者も、実際に「よりあい」の登録を行おうとすると本 登録のためのメールを受信できない（PC からのメールをブロックする設定を行っている）、パス ワードなどがわからず設定変更ができないなどの困難が生じた。

これらの結果を踏まえ、協議会でも互助のあり方を議論した結果、まずは拠点で多世代を集め ること、次に集まった高齢者と子育て世代間をつなぎ、助け合う関係性に発展するように支援す るといった方針が確認された。そのため、「よりあい」活用モデルの実装と普及は達成できなかっ た。しかし、後述する別プロジェクトの一環として東京都大田区大森地区にて、ICT 操作が不得 意な高齢者に代わり、常設型の拠点のスタッフが「よりあい」を操作するモデル（以降、大森モ デル）の実装から得た知見を踏まえると、現在の中高年が後期高齢者となった場合には「よりあ い」が活用される可能性が示唆された。また、大森モデルの知見に基づき「しもぞう八ウス」で の「よりあい俱楽部」(北区) および「中野島ファミリーカフェ」(多摩区) でのアナログ版互助モ デルを開発し実装することができた。

\section{2. 大森モデルに基づく都市部で住民互助を促す機序}

東京都大田区大森地区に開設した常設の多世代交流サロンを助け合い拠点とし、多様な多世代 交流イベントや講座を通した交流プログラムを実施した。その上で、これら多世代交流プログラ ムと同拠点での日常的な交流に基づく「よりあい」を活用した互助を促した。同プロジェクトで はスマートフォン等 ICT 利用が困難な高齢者には、拠点スタッフが操作を代行する「人を介した よりあい実装モデル」とした。

交流プログラムや拠点には、高齢者と主に乳幼巟連れの子育て世代が日常的に集うようになっ た。しかし、交流プログラムと拠点利用から、二つの世代が互助に繋がる交流を持つこと、およ び互助に繋げることは困難であった。そこで、拠点利用者や交流プログラム参加者を対象に、多 世代共助を目的とした「よりあい交流会」を平成 29 年 10 月〜平成 30 年 6 月まで開催した（全 14 回）。交流会では、交流を促すプログラムとして簡単な調理を共に楽しむ、お互いの支援ニー ズを顕在化させる「お互いさまゲーム」をおこない、「よりあい」登録と交流会参加者間での互助 を促した。その結果、26 件の多世代住民間互助に繋がった。

互助の内訳は ; (1)高齢者間互助 ; 4 件（買い物の付き添い等）、(2)近隣の事業所の職員が有償ボ ランティアとして支援 ; 4 件（荷物の運搬、浴槽の掃除等）、(3)高齢者が子育て世代を支援 ; 11 件 (衣服の修繥、家の片づけ等)、(4)子育て世代が高齢者を支援 ; 5 件（不要な書籍の整理とリサイ クルショップヘの販売代行、スマートフォン操作の教示等）、(5)子育て世代間 1 件（美容関係の相 
談)、(6)研究班スタッフが高齢者を支援 1 件（浴槽のエプロンの取り付け）。

その一方で、「お互いさまゲーム」で支援ニーズが表明されたにも関わらず交流会内で支援者が 現れない、ニーズを表明したが実際には支援依頼を行わない事例も複数あった。加えて、最初の 互助をきっかけとして継続的な互助へとつながったものは 1 組にとどまった。

交流会の参与観察とその後のヒアリング調查により以下の知見が明らかになった； (1)衣服の修 繥や子供の登園バックの作成など縫物に関寸る支援は子育て世代にニーズが高く、高齢者が役割 意識をもって対応可能な支援であった、(2)スマートフォンなどの機器操作支援は高齢者世代に支 援ニーズが高く、子育て世代が抵抗感なく対応可能な支援であった、(3)ただし(1)と(2)は拠点内で 完結する場合の夕支援提供者と依頼者双方にとって抵抗感が低かった、(4)日常的に拠点を利用し ている者にとっては拠点での互助は成立しや寸いが、交流会でのみ拠点を利用する者にとっては 拠点内での互助は「そこまでしなくても何とかなる」といった考えから支援依頼に至りにくかっ た、(5)交流会参加者同士は拠点利用時または地域の講座などでお互いに顔見知りではあったが、 直接的な交流は「よりあい交流会」をきっかけとしていた、(6)前述の(5) と関連して、交流会での 調理や「お互いさまゲーム」を通して「自分と価值観が合う」「依頼内容や生活の様子を評価しな い、他者に言わない」「清潔感がある」と判断した人に対して支援を依頼していた、(7)互助が行わ れた際に、お互いに(6)の様に感じたペアが互助をキッカケに信頼関係を醇成し継続的な互助につ ながっていった、8買い物支援や居室に入る支援は支援者側は責任が重すぎると考え支援提供を 躊躇しがちである、一方で9)高齢者においては居室に入る支援等は「そこまで頼んでよいのか」 といった躊躇があり、むしろ専門業者や町会等による有償ボランティアの方が依頼しやすい。

これらの結果を踏まると、交流拠点で住民互助を発生させるには次のステップが必要な可能性 が示唆された; Step1 拠点に各世代を集める、Step2 各世代にその拠点を「自分たちの居場所」 と感じてもらう、Step3 多世代（この場合は子育て世代と高齢者世代）が拠点で顔を合わせるよ うにする、Step4 顔見知りになったところで信頼関係の醸成と互助のきっかけづくりの介入 (例 えば「お互いさまゲーム」）を導入する。

また、コーディネーターを介さない住民間互助においては、支援提供に際し求められるスキル の高低または依頼者の居宅内に入りこむ等のプライバシーへの踏み込み度合、支援対象者の身体 的自立度に応じて、適した支援提供者や提供形態が変わる可能性が示唆された（図 3 )。「よりあ い」による近隣住民同士の直接のやり取りによる互助は、自立度の高い高齢者を対象とし、拠点 内で完結できる簡易な支援に適している可能性もある。簡易な支援で関係性を深めた者同士、ま たは簡易な支援を体験して互助への抵抗感が低くなった者では居室内に入る、より「踏み込んだ 互助」が可能かもしれない。加えて、居室に入る等の踏み込んだ互助は例えば町会等の信頼おけ る組織が運営するボランティアベースであれば可能かもしれない。 


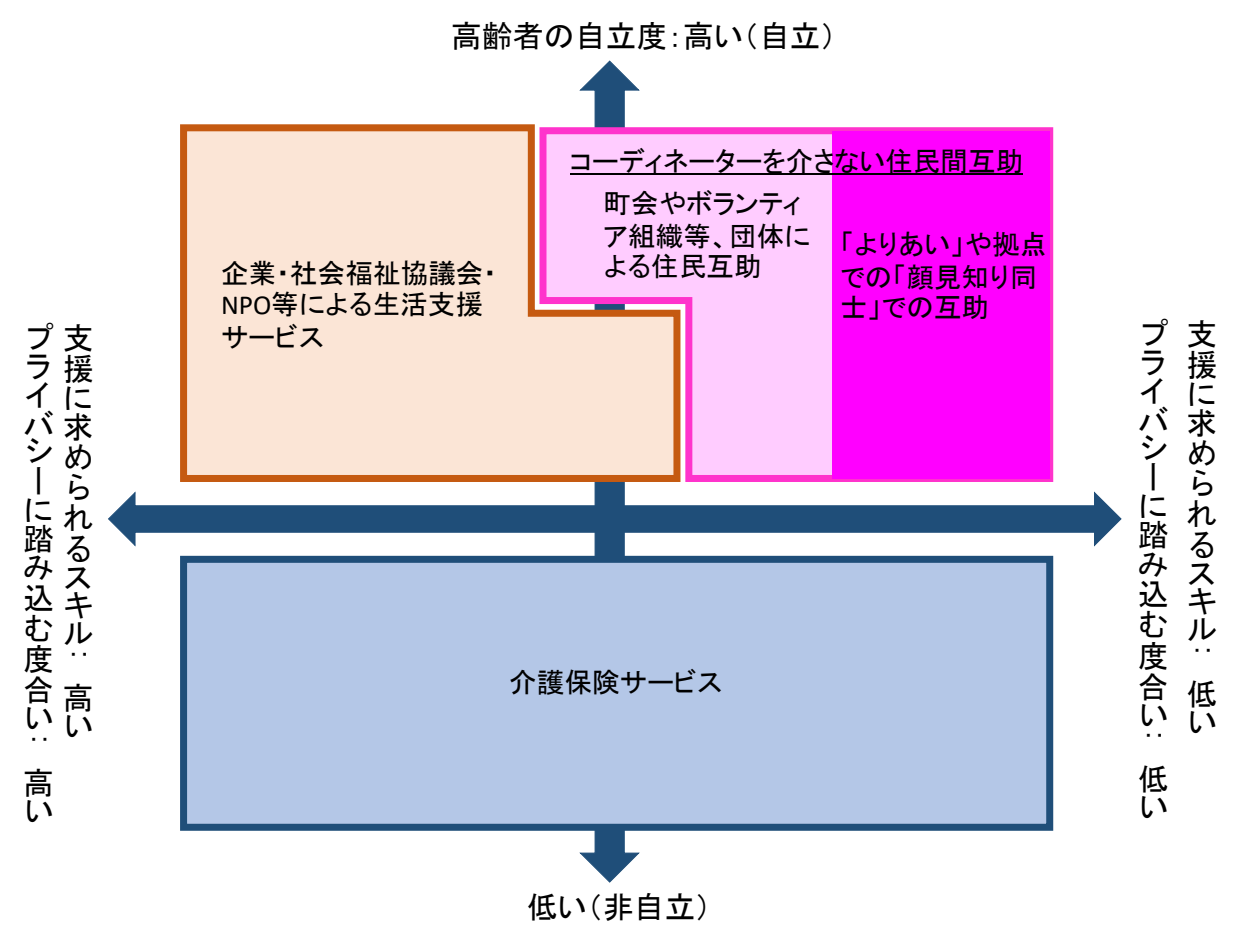

図 3 被援助者特性と支援ニーズに応じた支援形態

3. 助け合い拠点「しもぞうハウス」の開設

平成 30 年 3 月に北区社会福祉協議会が空き家（1 階部分に空き店舗を含む）を活用し、志茂地 区の支え合い拠点として地域小規模活動拠点を開設できたことから、多世代交流を基盤とした多 世代住民間の互助を確立する基盤が整ったと考える。なお、「しもぞう八ウス」という愛称は協議 会が提案した名前である。協議会では子どもから高齢者を含む全世代が親しみを感じる場所とな るような名前を考えた。同拠点に隣接する寺院の前に象の銅像があることにちなんで「志茂」と 「象」を合わせて「しもぞう」とした。

「しもぞう八ウス」開設には、本プロジェクトが影響していることが関係者への聞き取り調査 から明らかになった。まず、同物件は志茂ジェネ協議会メンバーが管理・所有しているが、同物 件を地域住民が世代を超えて集い、支え合い拠点として公益性の高い社会福祉協議会に活用して もらうことを希望したことが聞き取り調査では報告された。日頃の地域活動の中で多世代が日常 的に集い、困ったことを解決できる場が必要と感じていたことが聞き取り調查で明らかになった。 また、志茂ジェネ協議会では、住民間互助は常設の場等拠点で日常的な交流を繰り返す中で自然 発生的な互助を導き出すべきとの議論が度々なされていたが、こうした議論も関連しているかも しれない。

また、社会福祉協議会は区から生活支援体制整備事業第 1 層コーディネーターを受託している。 世代を超えた助け合い活動を支援していくことは、生活支援体制整備事業および社会福祉協議会 が推進する地域共生社会の趣旨とも一致すること、および志茂ジェネ協議会が多世代共生・多世 代共助を推進していることを踏まえ、「しもぞう八ウス」を常設の助け合い拠点として開設するこ ととした。

現在の「しもぞう八ウス」での活動は ; (1)まちプロによる「よりあい俱楽部」での互助モデル、 (2)地域の読み聞かせグループが来場者のリクエストに応じて読み聞かせをするといった絵本を通 した世代間交流、が主である。「よりあい俱楽部」では、まちプロが地域包括支援センターに配置 
された第 2 層生活支援コーディネーターおよび社会福祉協議会の第 1 層生活支援コーディネータ 一の支援を受けつつ、毎回のプログラムを検討している。また、各まちプロがそれぞれのネット ワークから毎回の講座講師（消防団に所属するまちプロが赤羽消防局職員を招き防災講座を開催、 まちプロの友人による手芸講座等）を招き、講座を実施するなど自主的な運営体制ができた。ま た、大森モデルの知見を発展させ、「よりあい俱楽部」内で実施可能な互助モデルの実装も開始し た。したがって、「しもぞうハウス」を拠点としたまちプロによる互助モデルは中期的には確立で きる見込みとなった。

今後については、社会福祉協議会と志茂ジェネ協議会では、この場を常設の支え合い拠点とす る方法を議論している。協議会では、例えば町会や「あいさつさん」または民生委員・児童委員 の有志の担当者が交代で「しもぞう八ウス」に常駐する案も出された。しかし、一個人や一団体 一依拠することは負担が高いこと、人材確保が困難なことから、活動場所を求めている地域の多 様な団体が、各団体の強みを活かして日替わりで瓦助に繋がる活動を運営する体制が提案された。 平成 30 年下期はこの体制の確立を目指す予定である。

4. 多世代交流拠点内でのアナログ形式による多世代住民間互助の確立

両モデル地区でまちプロが多世代交流拠点を開設し運営を開始した。北区では協議会と社会福 祉協議会の支援のもとで「しもぞう八ウス」にて「よりあい俱楽部」が月 2 回開催されることと なった。同様に、多摩区でも協議会の支援のもと中野島会館（町会の会館）にて「中野島ファミ リーカフェ」が月 2 回開催されることとなった。大森プロジェクトで得た知見に基づき、それぞ れの拠点にて多世代交流カフェを基盤とした互助モデルは確立しつつある。

北区では、「よりあい俱楽部」にて二つの方法で互助を推進している。第一の方法として、まち プロが「よりあい俱楽部」内で対応可能な支援項目（それぞれのまちプロの特技など）を建物の 外から見える掲示板で提示している。第二の方法として、「よりあい俱楽部」の中で身近な地域の 助け合いにつながる講座やイベントを企画し、参加者同士の交流の中で支援ニーズを引き出すと 共に、支援の担い手が拠点に集うような働きかけをまちプロが主導して行っている。

多摩区では、毎月第 2 と第 4 金曜日に「中野島ファミリーカフェ」を運営しているが、第 4 金 曜日は、カフェの中で瓦助の発生を促すため、まちプロの特技を活かしたブースを複数設置し、 参加者同士やまちプロによる「お助け」が発生するよう運営している。すなわち、子育て世代の まちプロによる「スマートフォンお助けブース」や、縫物が得意な高齢者まちプロによる「裁縫 お助けブース」や、絵本の読み聞かせボランティアを実施しているまちプロによる「絵本読み聞 かせブース」などを開催している。

まちプロの拠点での互助モデルは確立しつつあるが、拠点外の日常生活下における互助の関係 性の確立には至っていない。しかし、前述の「3-1. 達成目標 1)」(緩やかなサポートネットワー クの形成）通り、多世代交流プログラムと互助モデル運営を支援する土台としての協議会を基盤 とした地域団体間のネットワークが形成されたことから、地域団体を基盤とした日常生活下での 互助にも発展すると考える。

実際に、協議会関係者への聞き取り調査から、プロジェクト開始前に期待していたこととして、 住民同士の世代を超えた助け合いがあったことが明らかになった。しかし、互助が Web マッチン グシステム「よりあい」を通した互助モデルであったことから、実現可能性のイメージができな かったことが指摘されている。当初の期待の達成見込みが立たない中で、協議会参加者も本プロ ジェクトへの関わり方が不明瞭であったことも指摘されている。

まちプロによる拠点を基盤とした互助モデルが確立されつつある中で、協議会もまちプロ・拠 点・地域団体との連携による互助の取り組みに意欲的になっていることも、聞き取り調查で示唆 された。特に、多くのまちプロがこれまで地縁組織が繋がっていなかった人材であり、地域の既 
存組織がまちプロのような新しい住民組織と連携する可能性を見出したことで、多様な地域団体 との横断的連携に基づく互助が発展しうる可能性はあると考える。実際に、北区の協議会が「し もぞう八ウス」を拠点に複数の地域団体で瓦助に取り組む議論が進んでいることも、その意識の 表れと考える。

加えて、両モデル地区では、協議会・まちプロ・地域団体をつなぐ等の調整業務を行っていく コーディネーター的な存在ができたことで、日常生活下での世代を超えた助け合いが実現しやす くなると考える。北区では、地域包括支援センターに配置された第 2 層生活支援コーディネータ 一であり、多摩区では地域包括支援センターがその役割を担うことが期待される。北区では、第 2 層生活支援コーディネーターは既に、協議会事務局として協議会で得たネットワークを活用し て団体間をつなぐ役割を果たし始めている（「3-1. 達成目標 1 . 緩やかなサポートネットワーク の形成」)。多摩区においても、地域包括支援センターはこれまで介護保険対象外の事案に対応し ていることから、住民互助の確立は喫緊の課題であると考えていた。交流の場の運営については、 発足当初からより積極的に関わるべきであったと考えており、現在では、まちプロ運営会議にも 参加し、まちプロと共に互助に繋がる場づくりに関与しようとしている。つまり、まちプロによ る活動を機に、地域団体の間で多様な形態の互助を生み出寸機運が高まり、本来住民活動を支援 するコーディネーターもこれら団体を支援する意欲が高まっているといえる。

\section{【結論】}

・Web マッチングシステム「よりあい」を開発し両モデル地区での実装を目指した。しかし、 高齢者の ICT 利用が限定的であること、支援ニーズを顕在化しにくいことから実装が困難で あった。多世代交流プログラムの中で交流を深めると同時に支援ニーズを顕在化させる「お 互いさまゲーム」を開発し、多世代交流プログラムの中で試行した。

- 大森プロジェクトでは、交流拠点で住民互助を発生させるに次のステップが必要な可能性が 示唆された; Step1 拠点に各世代を集める、Step2 各世代にその拠点を「自分たちの居場 所」と感じてもらう、Step3 多世代（この場合は子育て世代と高齢者世代）が拠点で顔を合 わせるようにする、Step4 顔見知りになったところで信頼関係の醸成と互助のきっかけづ くりの介入（例えば「お互いさまゲーム」）を導入する。

- また、大森プロジェクトでは、コーディネーターを介さない住民互助は、まずは拠点内で解 決できる簡易な支援から互助関係を作ることが重要という知見を得た。この知見と「よりあ い」の実装状況を踏まえて、協議会で互助モデルの実装方法を議論した結果、両モデル地区 で開設された多世代交流カフェでの多世代交流に基づくアナログ形式の互助モデルを確立す ることとした。

- 北区社会福祉協議会は志茂ジェネ協議会と行政の協力のもと、空き家を活用し、志茂地区の 支え合い拠点として「しもぞう八ウス」を開設した。

- 北区では協議会と社会福祉協議会の支援のもとで「しもぞう八ウス」にて「よりあい俱楽部」 が月 2 回開催されることとなった。北区社会福祉協議会とモデル地区内の地域包括に配置さ れた第 2 層生活支援コーディネーターが生活支援体制整備事業の一環として「よりあい俱楽 部」運営を支援している。行政施策の枠組みの中で、地域のネットワークの支援を受けるこ とで、継続的かつ安定的な活動が担保できることが明らかになった。

- 多摩区では協議会と地域包括の支援のもと中野島会館（町会の会館）にて「中野島ファミリ 一カフェ」が月 2 回開催されることとなった。住民互助の確立を喫緊の課題としている地域 包括がカフェ運営を積極的に支援している。

- 大森プロジェクトで得た知見に基づき、「よりあい俱楽部」と「中野島ファミリーカフェ」に て多世代交流カフェを基盤とした互助モデルは確立しつつある。 
- まちプロによる多世代交流カフェでの互助の実装を踏まえ、協議会の主な構成団体である地 域の既存組織がまちプロのような新しい住民組織と連携する可能性を見出した。協議会では、 拠点外の日常生活下における互助の関係性の確立に向けた議論が進んでいる。

\section{3-2. プロジェクトのリサーチ・クエスチョンへの回答}

(達成目標 2 に対して)

Q1. 地域における世代間の信頼感は、世代間の緩やかなサポートネットワークを形成することに より高めることが出来るのか?

A. 地域の多様なイベントにてクリアケースや缶バッチを配布し、本プロジェクトをPRするとと もに、挨拶の重要性に関する普及啓発をおこなった。それにより、地域で本プロジェクトの 周知は徐々に進んでいるとは考えるが、一般的な地域住民同士のサポートネットワークの形 成は不十分である。しかし、北区においては、協議会の支援のもと複数の地域団体があいさ つさんの取り組みに参画していることから、中期的には世代間のサポートネットワーク形成 が期待できる。

（達成目標 2 に対して）

Q2. 多世代交流の場にて、高齢者世代と子育て世代が何らかの協働作業を積み重ねるプログラム とその中で両世代を積極的に繋ぐ人材がいれば、両世代の交流が発生するのか?

A. 協働作業を積み重ねるプログラムを体験することは、世代間の交流には有効であることは、 様々なタイプのプログラムを実施して明らかになったと言える。また、まちプロのような積 極的に両世代を繋ぐ人材は交流には不可欠である。一方、そうしたプログラムの展開方法や、 交流の進め方、および繋ぐ人材の資質や関わり方は、様々な要因に影響されるため、より標 準化するために知見の蓄積と明文化が必要である。

Q3. 多世代交流の場にて、個人の生活上の課題を顕在化させる仕掛けがあれば、支援ニーズは顕 在化するのか?

A. 交流の場で各世代が自身の「困り事」をイメージ出来ないことから、お互いさまゲームを開 発・導入した。お互いさまゲームは、ファシリテーターの進め方により困り事を顕在化させ るのには一定の効果があった。一方で、一回のグループが 7 名以上等の大人数である、十分 な交流が図られなうちに導入すると発言出来ない高齢者がいる可能性も示唆された。以上の ことから、ゲーム実施のグループサイズやタイミングを熟慮する必要があると考える。

Q4. 顕在化したニーズは、他者への支援を求める仕掛けがあれば交流プログラム内で互助のマッ チングは成立するのか?

A．お互いさまゲームではニーズがある程度、顕在化出来たが、助け合いまでには至らなかった。 交流プログラムに継続的に参加し、ある程度、参加者間での会話が弾むようになった際に、 顕在化したニーズに助けを申し出る可能性が示唆された。また、ニーズが顕在化した際に、 まちプロがどのように声掛けするかを明確化することも必要と考える。

Q5. 子育て世代ならではの高齢者支援とは何か

A. スマホ講座にて実施した子育て世代のサポートは、子育て世代ならではの高齢者支援の一例 として潜在的なニーズが大きいことが明らかになった。一方、子育て世代でも乳幼児を抱え 
る親は身体的な制限が高齢者以上に高い場合が多いこと、両世代とも家の中に入る・入られ ることに抵抗感あることを踏まえると支援を提供する「場」が重要となる。例えば、本プロ ジェクトで実施しているような場所にて実践することが望ましいだろう。

Q6. 高齢者世代が抵抗感なく参画できる子育て支援と何か

A. 高齢者による子育て支援は、高齢者の身体機能と子どもの年齢に影響を受けることがわかつ た。健康度が極めて高い前期高齢者の場合は、拠点となる場所にて乳幼児の世話（例えば、 母親が食事やお茶を楽しむ間にあやすなど）をすることに対して、高齢者も子育て世代も抵 抗感が低い。一方で、自立はしているが足腰その他の体の筋力に衰えが見える高齢者が、親 に代わりあやすなどの世話をすることは、両世代が不安を感じやすい。しかし、このようや 若干の健康課題をもつ高齢者であっても、未就学児（4 歳以上）の支援においておいては、例 えば子どもの反応を丁寧に読み取りながら読み聞かせをする、あやとり等の昔遊びを教える などができていた。そして、これらの支援は子育て世代にもニーズが高いことが明らかにな った。また、多世代交流プログラムでは、縫物が得意な高齢者を中心にクリスマスの飾り等 を作成した。そこでは、子育て世代が高齢者に代わり針に糸を通し、高齢者が子育て世代に 縫い方を教示する光景が見られた。以上のことから、縫物を通した支援は両世代が受け入れ や寸い可能性がある。

（達成目標 3 に対して）

Q7. 多様な背景をもつ子どもへの居場所・学習支援の充実は，困窮家庭の生活基盤の改善につな がるのか?

A. 改善することが期待されるが、現状その把握は難しい。

（達成目標 $1 、 2 、 3 に$ 対して）

Q8. 各協議会メンバーとその所属団体にとって他分野との連携が自組織の活動にメリットがある 事を実感・認識すれば、横断的連携が醸成・維持されるのか?

A1. 地域の既存団体の活動は、その目的や運用方法が長年固定化されているものであり、他分野 との連携にメリットを見出すには、大きな変化が必要とされる。中野島つながり愛フォーラ ムのようなイベントで、既存団体には属しない住民と地域の課題について議論し続けること が出来れば横断的な連携が醸成される可能性があると考えられる。

A2. 地域の団体にはその団体固有の目的と固定化された取り組みがある。また、会社組織と異な り、明確な達成目標およびそれを達成する客観的な動機（資金確保等）が薄い。そのため、 新たな連携に取りくむことによるメリットを見出しにくい可能性が示唆された。一方で、協 議会で取り組むプロジェクトの目指すビジョンが団体のビジョンと一致している、および取 り組むプロジェクトによるビジョン達成の実現性が高い場合は、横断的連携が醸成・維持さ れると考える。

Q9. 多分野の組織が多世代共創を目的としたプログラムやイベントの開発・運営で協働すること で、横断的連携は進むか?

A. 多世代共創は、横断的な連携を生みやすいテーマであることは、本年度実施した様々なイベ ントからも明らかではある。一方、そうしたテーマの重要性やそれを支える体制、資金的な 支援を継続的に必要とするものであり、既存の団体や行政組織は必ずしもそうした支援を行 うものではない。特に、資金的な支援については、大企業の CSR もしくは CSV を考慮した プラットホームの構築も検討すべきと考えられる。連携に参画する組織内の価值観や運営も 
合わせて変化、または対応できるような検討が必要である。

\section{3-3. 領域のリサーチ・クエスチョンへの回答}

以下では、領域のリサーチ・クエスチョン（平成 30 年 1 月現在）を簡略化して見出しとしています。全文に ついては、下記をご参照下さい。

領域 WEB : http://ristex.jst.go.jp/i-gene/introduction/research-question.html

\section{領域-Q1．持続可能な社会に向けての多世代共創の意義とは？}

世代間や多世代という言葉はこれまでその意味や具体的な手法の十分な議論や検証がなされな いまま便宜的に使われてきたことが多い。何かを実現するための多世代的なアプローチは、その 意味と具体的な手法が、既存の意識やあり方を変えられるよう全てのステークホルダーに見える 化することと、既存の仕組み（組織や業務、慣行など）にメリットがあるものとして受け入れら れることが必要である。

本プロジェクトのモデルは、特に行政や地縁組織との結びつきが強かったことから、多世代共 創の意義についての理解はされやすかったものの、実装する具体的な内容での議論の過程では、 各組織の考え方や方法の調整で難しさを感じることが多かった。こうした過程の中では、地縁組 織ではない立場の意見や若い世代からの意見に勇気づけられたり、参加者が同意しやすかったり する場面も多くあり、横断的な関わりの重要性を感じられた。地縁組織の代表的な立場の住民か ら若い世代が関わらないという声は全国で聞かれる声ではあるが、実際にそうした意見を出す側 が具体的に若い世代にアプローチをしていないことも多い。また、こうした地縁組織を支援する 立場にある行政や専門職も、多世代型のアプローチやその強みについて十分理解できていない。 リビングラボや、フューチャーセッションなどのような既存の会議とは違う場での議論の機会を 増やしながら、幅広い世代が参加しやすい入口を広げていく取り組みが持続可能な社会にむけて 必要であると考える。

\section{領域-Q2．特に若い世代が多世代共創的活動に参加するインセンティブとは？}

若い子育て世代にとってのインセンティブは自身の子育てに関する具体的なメリット（子育て の知識、自身の教養や体験、預かりなどの支援）が明確なことである。それらメリットの受領は、 特に多世代的な機会や環境である必要はなく、公的、民間を含めて様々な機会やサービスが提供 されている。一方、多世代の環境でそのようなメリット以上のものを見出す参加者が多いことも プロジェクトの活動を通して幾度も実感した。同世代では話しにくいことも、異世代だからこそ 気軽に話せるというのは、交流の場で多く聞かれた声である。

また、子育て世代のまちプロから、高齢のまちプロと接することで、仕事の体験談などを聞く ことがあり、自身の将来の職業を考えるうえで参考になったという声が聞かれた。地域の交流や ボランティア活動に参加することによって、子育て中の多くの女性が仕事に復帰するうえで抱え る不安などの軽減につながることが示唆される。海外の研究などでも、ボランティア活動をして いる人の方が職場復帰が早いという報告もあることから、不安の軽減だけでなく、多世代での活 動に関わることで身近な仕事につながるネットワークが広がる可能性がある。このような多世代 のネットワークに加わることのメリットを打ち出した啓発が、保育や学校現場、高齢者の活動の 場で必要であると考える。 


\section{領域-Q3．効果があるのに多世代共創に参加しない場合の世代別の方策とは？}

多世代共創に参加しない層は、子育てや、高齢者などの特定の世代に偏っているというより、 各世代において一定割合存在していることがより大きな障壁である。ジェネラティビティという 指標において、若い世代、中高年、高齢世代とも大きな違いはないことが本プロジェクトで実施 した住民調査でも示されていることから、各世代とも次の世代へ何かを残したいという思いに大 きな違いはないと考える。

むしろ、他世代との関わりからネガティブな経験が繰り返されることが、多世代共創参加の障 壁になっている可能性もある。本プロジェクトが実施した、若い世代への聞き取り調査では、子 育て世代が日常的に、地域の見知らぬ高齢者から否定的な言葉を投げかけられる体験をしている 場合があることもわかった。このようなネガティブな体験が、他世代に対する拒絶感と、同一世 代で固まる嗜好を強める結果になっていた。こうした世代間のネガティブな側面についての実態 は社会全体であまり注目されず、むしろ世代間の対立を助長するかのような報道も多い。

その結果を踏まえて、多世代共創への参加を促すには、意義のある世代間交流を継続的に実施 することにより、他世代に対する信頼感を高め、多世代共創することによりポジティブな体験を 繰り返すことが重要と考える。

しかし、まずは多世代共創の入り口ともいえる多世代交流のあり方の見直しが必要である。例 えば、教育現場、特に小学校の現場では、地域と学校の連携の中で、学校教育のプログラムや環 境づくりの一環として、多世代の住民との交流がなされてきた歴史がある。しかし、その交流の 多くが単発的なものであったり、交流の目的が明確ではないものであることから、他世代と交流 する意義や、一時的に向上した意識が持続しないまま、より交流が減少する高学年や中学、高校 へと進んでしまう。そこで、地域に多様な形態の多世代共創に繋がる活動を創りだすことで、他 世代とポジティブな関わりができる機会を増やす必要がある。

\section{領域-Q4．持続可能な社会及び多世代共創における新技術の影響や含意とは？}

よりあいのようなマッチングシステムの技術に対するニーズは潜在的に高いと言えるが、本プ ロジェクトで明らかになったように、通信デバイスを使った技術を高齢者層に展開する環境は整 っていない。それはデバイスを所持していても、どの程度、何の目的で利用しているかが非常に 限定的であるという実態があるからである。こうしたデバイスの保有率や利用実態は、今後どの ような新しいシステムを導入するにせよ課題になることが考えられる。また、高齢者の生活に密 接に関わる新技術は、技術の導入のプロセスがより丁寧かつ、手厚いサポート体制が必要であり、 技術開発のサイクルと相いれないことが容易にありうる。そのようなシステムの基盤がどのよう なテーマで発展するとより浸透しやすいかの検証が必要だと考える。

高齢者世代への新技術の導入に際しては、「今の高齢者世代に使い易い形態や機能」または、高 齢者の新技術利用を支援する体制がいつの時代でも必要になると考える。「よりあい」実装に関す る聞き取り調査では「10 年後の高齢者は利用できるだろう」といった意見が多数寄せられた。し かし、10 年後は新たな新技術が導入され、その時の高齢者が必ずしも利用できるとは言い切れな い。通信デバイスを利用した新技術は、現在保有している多くの若者をターゲットにした開発が 中心であるが、今後のデバイスの高齢者層への普及にともない、市場規模の大きさから若者から シニア層をターゲットとした新技術開発にシフトしていくのではないかと考えられる。 


\section{領域-Q5．多世代共創的活動は人々にどのような意識変化をもたらすか？}

世代間交流を通した意識の変化について、他の世代に対する認識や感情、行動する意識の変化 など先行研究は多い。一方そうした意識の変化は持続しないと報告している研究も多い。社会に おける人の成長の段階で接する他世代の相手は変化し続け、家族や親族以外では多世代との関係 性が長期に亘ることがない。

その一方で、ライフコースのどこかの時点で多世代共創的活動に関わることで、他世代に対す る信頼感、地域社会に対する意識、仕事や子育ておよび高齢期の過ごし方に関する考え方等、多 岐に渡る意識変化を起こす可能性もある。

本プロジェクトの聞き取り調查により、若いまちプロが、高齢者まちプロとの共創活動として 多世代交流カフェを立ち上げ運営する中で、高齢者世代に対する尊敬の念、仕事や子育てに関す る考えに影響を受けたとの報告もある。同様に、別の多世代交流カフェの運営スタッフへの聞き 取り調查により、子育て中に地域の高齢者から冷遇された経験から、高齢者世代に否定的な意識 をもっていたことがわかった。しかし、高齢者まちプロが、多世代交流カフェの中で自分の話を 「評価することなく全てを受け入れ、励ましてくれた」「バスで会った時に話しかけてくれた」と いう経験を得る中で、高齢者へのイメージが好転した上に、地域に対しても愛着や一体感を持っ たことが報告された。

\section{領域-Q6. 多世代共創が社会に普及・定着するには？}

社会実装する条件の一つに、関係者の強い動機付けの必要性がある。地縁組織、専門職、民間 企業いずれも、何か新しい試みをするにはそれに対してどの程度コミットできるかを検討しなが ら関与していく。最も困難な事は、地縁組織や地域住民には、熱心な賛同者から無関心な人まで 様々な意識で関わるため、その動機の程度を推測し、いかに強い動機に変化させていくかである。 本プロジェクトでは検討事項の見える化（資料のわかりや寸さ、検討中の発言を模造紙に書いて いく、前回会議のふりかえりをするなど）に配慮したことは評価されている。

また、本プロジェクトを通して、動機付けされた関係者たちで構成される地域のネットワーク が重要であることも明らかになった。多世代交流を基盤とした互助モデルの確立は、予測以上に 時間を要したが、協議会と具体的な取り組みを繰り返していく中で、地域のネットワークが醸成 された。このネットワークが社会実装の定着と普及の基盤となっていた。本プロジェクトでは、 関係者にある程度の動機づけができた段階で、例えば北区の志茂ジェネまつりや多摩区のフォー ラムのように、具体的な取り組みを通して、関係者が取り組みの趣旨を地域に伝える中で動機付 けを強めると共に、新たなネットワークを築いたことも評価されている。

本プロジェクトのように住民の福祉に資する PJ は自治体の施策と連動せざるを得ない。今後、 国および自治体の福祉施策の基盤は、共生社会と地域包括ケアシステムである。これらの実現が 喫緊の課題であるが、両者の融合に笨する自治体が大半である。本 PJ はその試金石と言え、行政 と連携を続けることが、着実かつ効果的であると考える。そのためには、自治体とは丁寧かつ頻 繁なコミュニケーションにより信頼を勝ち取ることが原則である。自治体は、学術機関と(包括)連 携協定を結ぶことや、役所の審議会に学識委員として参画を求めることもあるので、それに対す る快諾も信頼獲得と施策反映に重要と思われる。 


\section{領域-Q7. 多世代共創の程度と持続可能な社会への有効性を評価するための指標とは?}

多世代そのものを評価するには構造的な指標（組織のメンバー構成や年齢層など）が考えられ るが、アウトカムは事業主体の意向により多岐にわたる。健康、意識、学力等様々な指標により 多世代型の試みが成果をもたらしたかどうか評価されるべきである。

\section{領域 Q-8．持続可能な社会及び多世代共創における地域の自然の意味とは？}

当 PJ は大都市モデルであり、地域の自然の影響は直接は受けない。敢えて言うならば、荒川と 多摩川に隣接している点は、住民の原風景になっている可能性はある。こうした環境は、交流プ ログラムの企画立案などで話題になることもある。また、啓発ツールの開発などでもこうした環 境を反映するデザインをするなど、住民に伝わりやすい工夫が必要だと考える。当 PJ のような 大都市モデルの場合には、自然よりもマンション開発などによる、住民層の変化、新住民 vs 旧住 民といった構図の方を捉えた取り組みが重要と思われる。 


\section{3-4. 実施項目毎の結果・成果の詳細}

\section{3-4-1．中高年から始める多世代挨拶運動}

- ジェネラティビティと多世代で挨拶し合うことの意義を普及啓発する 15 分程度のミ二講座 を開発し、地域活動団体の定例会や地域イベント等で実施した。

- 北区では、上記のミニ講座を町会・自治会 (町会長会議と、各町会・自治会の役員・定例会)、 民生委員児童委員協議会、青少年地区委員会役員会を対象に計 15 回、延べ 450 名に実施し た。小・中学校や地域のイベントでロゴマークを記載したクリアファイル約 2,000 枚やリス トバンドを配布し、ジェネラティビティと挨拶の重要性を普及啓発することができた。

- 多摩区では様々な地域イベント（町会の避難訓練や中野島音楽祭等）でロゴマークを使って 作成したクリアファイル約 3,000 部、および午バッチ約 3,000 個およびリストバンドを配布 し、ジェネラティビティと挨拶の意義を普及啓発することができた。この結果、地域の行事 である中野島音楽祭で、来場者に対してのアンケート調査をする中で、キャンペーングッズ の認知度の高さがうかがえた。

- 北区では 110 名の「あいさつさん」登録者を集め、プロジェクト終了後も継続的に活動を行 う体制ができた。具体的には、毎月第 2 金曜日に「あいさつさん」定例会を設置し、志茂地 域振興室・志茂ふれあい館にて定期開催をしている。普段は個々の「あいさつさん」が日常 生活の中、あるいは地域イベント参加の際にストラップを身に付けて挨拶を実践しているが、 それに加えて定例会後半にチームでの挨拶運動を取り入れることによって、活動を強化する ことができた。

・志茂ジェネ協議会がプロジェクト終了後もあいさつさんの取組みを推進することを確認し、 地域団体が継続的にあいさつさんに取り組む体制ができた。

- 多摩区では、プロジェクトの趣旨に共感した地域の集合団地（新多摩川ハイム）が、住民が 運営する地域活動に関するホームページにおいて中野島つながり愛プロジェクトを紹介する ページを作成した（http://heimnohiroba.com/category/heimlife/chiiki/tasedai/)。また、中野 島町会が運営するホームページ（http://www.geocities.jp/nakanoshimatyoukai/) においても、 本プロジェクトについて紹介されており、中野島地域全体で啓発の輪が広がっている。

\section{3-4-2. 多世代交流を基盤とした多世代住民間互助の確立}

- 多世代交流プログラムの企画と運営、および交流を基盤とした互助を促すまちプロを北区で は2 3 名、多摩区では 18 名育成することができた。それぞれの地域で多世代からなるまちプ ロが自主的に活動するようになっている。

- 北区では協議会参加団体である「ほっこり〜のプラス」が運営する子育てサロンにて、毎週 火曜日に「多世代交流 day」が設定されるようになり、北社協志茂地区小地域活動拠点（通 称、しもぞう八ウス）での「よりあい俱楽部」とあわせて志茂地区での多世代交流が進めら れている。

-「お互いさまゲーム」の開発・実施により、多世代交流プログラムの中で参加者同士が「互 助」を意識しながら交流することが可能となった。まちプロがゲームの実施に慣れてくるこ とによって、プログラムから互助へのつながりが容易となりつつある。

- 北区社会福祉協議会が北社協志茂地区小地域活動拠点（通称、しもぞう八ウス）を当該地区 における新たな交流と支え合いの拠点として開設した。北区社会福祉協議会は、区からの受 託事業である生活支援体制整備事業における第 1 層生活支援コーディネーター業務の一環と して、この「しもぞう八ウス」での「よりあい俱楽部」を支援している。これらの経緯を踏ま 
えると、「しもぞう八ス」は生活支援体制整備事業の枠組みの中で、協議会・自治体・北区社 会福祉協議会・地域包括支援センターに配置された第 2 層生活支援コーディネーターの支援 のもと、地域人材まちプロが運営する地域の支え合い拠点ができたといえる。

・ 上記「しもぞう八ウス」にてまちプロが多世代交流の拠点「よりあい俱楽部」を開設し、自 主運営をおこなっている。常設の場が出来たことによって、まちプロの多世代交流の場づく りの取り組みに対する意識がより具体的、積極的になってきている。近隣との関係性や配慮、 通行人に対する取り組みなど、単に公共施設を借りている活動とは違った意識を持って活動 が出来ている。

-「しもぞう八ウス」を地域の助け合い拠点とするため、まちプロが「よりあい俱楽部」にて アナログ形式の互助を推進している。具体的には、掲示板を通じてまちプロが「よりあい俱 楽部」内で対応可能な支援項目（それぞれのまちプロの特技など）を発信する取り組みや、 身近な地域の助け合いにつながる講座やイベントの企画および「お互いさまゲーム」の活用 により、参加者同士の交流の中で支援ニーズを引き出し、支援の担い手が拠点に集うような 働きかけをまちプロが主導して行っている。これらの手法は、別事業で実施した知見に基づ いている。

- 多摩区では、上布田カフェに加え、平成 30 年 3 月から、第二・第四金曜日に中野島公民館に て「中野島ファミリーカフェ」が多世代交流拠点の中核となってきた。3 月から計 234 人が 参加している。ストレッチ体操などの運動系からハーバリウムづくりなどの工作系まで、子 育て世代と高齢者が楽しめる内容を、毎回まちプロが企画し運営している。地域の講師など も積極的に活用したり、PR 方法の検討など、事前の打ち合わせや事後の反省会など自主的に 実施できている。可能な限り互助につながる交流の場になるよう、子育て世代のまちプロに よる「スマートフォンお助けブース」や、縫物が得意な高齢者まちプロによる「裁縫お助け ブース」や、絵本の読み聞かせボランティアを実施しているまちプロによる「絵本読み聞か せブース」などを開催している。

- 中野島で実施しているポールウォーキングは、定期的な活動の他、地域の保育園との交流活 動を開始した。協議会メンバーでもある保育園と協議をしながら、園児との交流が実現した。 自らの健康増進に興味を持つだけでなく、次世代との交流をとおしたジェネラティビティの 醸成が進んでいる。これらの多世代交流イベントにおいて、身体機能が低下し、自力での参 加が難しい地域住民に対しては、まちプロを中心に外出の補助をしながら交流の場への参加 を促している。

【両モデル地区共通課題】

- 昨年度以来「よりあい」の課題としては、(1)高齢者のスマートフォン利用率の低さ、(2)高齢 者のスマートフォン利用方法が限定的であること、(3ITリテラシーの対応、(4)インターフェ ース上の問題、(5) 支援ニーズの問題（低さ・抵抗感）が挙げられた。

- 介護保険などで受け㿼のないグレーゾーン的な困りごと・支援ニーズ（庭の水やり、家の掃 除、買い物等）を「互助」の仕組みに乗せていくことで利用を促すことができる可能性が見 いだされた。

- 顔見知りだからこそ、頼みにくいこともあり、中でも家の中に入られることは、知り合い同 士でもハードルが高いことが明らかになった。

- 支援ニーズの低さ・抵抗感に関して、「よりあい」で扱う支援が「頼まないと生きていけな い」わけではない内容であるからこそ、本人から頼み辛いことが明らかになった。

- 平成29年度は「よりあい」の本稼働を開始し、普及に向けて、(1)「よりあい」導入に至る前 段階として、多世代交流プログラムの中で世代を超えた互助を体験できるグループワーク 
「お互いさまゲーム」を開発し、(2)北区ではシニア世代のWebシステム登録者を増やすた め、「シニアのためのスマホ講座」を開催した。

- 上記と並行して、協議会および作業部会で「よりあい」普及上の課題と対策について検討を 行った。

- 当初計画で予定した「よりあい」の実装は、様々な取り組みを試行したが、その結果として 導入が進まないことが判明した。これを受けて、「よりあい」にこだわらず、多世代交流の 場において当事者同士で助け合いに関するマッチングを行える仕掛けや仕組みを開発するこ ととなった。

【両モデル地区共通成果】

a)お互いさまゲーム

- 異なる世代の住民間で「助け合う」ということを体験し、身近に感じる仕掛けの必要性から、

「お互いさまゲーム」を開発し、多世代交流の場などで試行した。お互いさまゲームは、(1) 付箋 (カード) 1枚に1つ自身の困り事を記入する、(2)記入した付箋(カード) を提示しながら、 詳細について話す、(3)全員で手伝えそうな内容について話し合う、の3つの基本ステップか ら構成されている。モデル区にて、専門職を対象にした研修にて「お互いさまゲーム」を試 行し、研修ツールとしての有効性が認められた。

- 多世代交流の場での「お互いさまゲーム」の実施を通じて、a）地域の日常生活支援は一方通 行の「サービス」ではなく、「お互い様」の意識を持った支え合いであること、b）支え合い は顔の見える関係づくりから始まること、c）支え手は一人で担う必要はなく、他の人と一緒 であれば力になれることを地域住民に啓発することができた。

・ お互いさまゲームを行うことで、参加メンバーがお互いのことをより深く知り合うきっかけ となり、交流の促進につながった。また、異なる世代が日常生活の中でどのような困りごと に直面しているのかが視覚的に明確となり、自分が支援を提供できる内容を具体的にイメー ジしやすくなった。

・ 課題として、グループワークの性質上、同じメンバーで繰り返し「お互いさまゲーム」を実 施することは難しいことが明らかになった。

-「お互いさまゲーム」実施直後に「よりあい」を紹介し、「よりあい」の普及に努めたが、中 高年・シニアはスマートフォンやタブレットといった機器自体の使用に困難を感じているケ ースが大半で、「よりあい」を使ったマッチングまで至ることはできなかった。継続して互助 の関係性を持ち続けるためには、ゲーム内で提示された困りごとをウェブなどではなく、ア ナログ的に掲示板などに情報集約し、それを介したマッチングの仕組みづくりを行う必要が あるという結論にいたった。

b)「シニアのためのスマホ講座」の開催

- 平成29年度は、前年度に協議会において挙げられた課題（高齢者のWeb活用が困難であり、 講座などを実施しながら普及に努める）に応えるため、北区において「シニアのためのスマ ホ講座」を開催した。

- 講座は、すでにシニア世代に対するスマートフォンなどの使用方法などの講座を開催した実 績のあるNPO法人シニアSOHO世田谷の協力のもと実施した。同NPO法人はシニアを対象に したタブレットやスマホ講座で豊富な実績があり、指導者がシニアであることから、講座の 内容だけではなく、日常の使用上での課題など細かなニーズを講座を通じて共有することが できた。

• 子育て支援をしているほっこり〜の志茂店を会場に開催したことから、よりあい使用時に世 
代を越えた互助が展開されることを見越して、近隣在住の子育て世代 2 名にスマホ講座のアシ スタントとして参加してもらうことを可能にした。

- 課題として、(1)iPhoneを使用すると銘打って講座を開催したものの、受講者の多くは指定以 外のデバイスを使用しているものが参加した。また、自身のスマートフォンが何かを十分に 理解していなかった。(2)講座で使い方が理解できても一人では操作できないという人も多く いた。(3)スマートフォンの基本的な操作を習得できた人も、実際に「よりあい」の登録を行 おうとすると本登録のためのメールを受信できない（PCからのメールをブロックする設定を 行っている)、パスワードなどがわからず設定変更ができないなどの困難が生じた。

- 参加者からのニーズとしては、店員からの説明が理解できないといった理由から、スマート フォン購入のためのツアーのようなイベントの開催、個別でスマホ操作の相談ができる場の 提供、定期的な「スマホ講座」の開催などが挙げられた。スマホの利用で多くの高齢者がサ ポートを必要としていながら、家族の間でも相談がしにくい状況にあることが明らかになっ た。こうしたことから、スマホに関する互助の可能性があることがわかった。

\section{3-4-3 多様な背景をもつ子どもへの学習・居場所支援の充実}

- 平成 27 年度に、子ども食堂の実態を把握するために、全国の優良事例 11 件を対象とした文 献レビューおよびインタビュー調査を実施した結果、多くの子ども食堂が子どもから高齢者 まで幅広い年齢層を対象とし、貧困世帯だけではなく、誰もが来や寸い場づくりを心がけて 活動していることが明らかとなった。また、継続的な取り組みにするためには、「ヒト（スタ ッフ・利用者の数）」、「モノ（建物や備品、そして食料）」、「お金（光熱費、広報代、家賃など の経費)」の整備が必要であることが見出された。

- 北区社会福祉協議会が北区内の学習・居場所支援を行う各種団体やNP0 を対象に開催したネ ットワーク会議（3 回）に参加し、当該団体・NPO との横のつながりを構築すると共に、北区 での取り組みの現状について情報共有を行った。北区内での、学習・居場所支援に関する情 報が継続的に入手できるようになり、志茂地区でのまちプロの活動の参考となるよう、情報 共有ができるようになった。

- ほっこり〜の志茂店で月一回開催中の子ども食堂において、まちプロがスタッフとして参加 し、多世代交流の場で培ったノウハウをもとに運営の補助を行っている。こうした経験が、 しもぞう八ウスの多世代交流の場において活かされるようになり、将来的にしもぞう八ウス の活動においてもよりニーズの高い子どもを対象にしたプログラムづくりにつなげていける ことが考えられる。

- 多摩区中野島で開催されている、子ども食堂と学習支援を提供している「こどもほっとスペ ース中野島」（川崎市の事業）で、まちプロがボランティアスタッフとして活動している。

\section{3-4-4. 多世代協議会の立ち上げと運営}

【北区の結果・成果】

- 平成 28 年 2 月より、北区志茂地区を支える地域活動団体の代表者や専門職、行政職員、企 業、研究者が参画する協議会（通称：志茂ジェネ協議会）を発足し、原則月一回のペースで 開催した。その結果、北区では当該協議会が生活支援体制整備事業*の第 2 層協議体 (中学校 圈域レベルの協議体）の位置付けで継続されることとなった。

- 志茂ジェネ協議会は、北区社会福祉協議会と自治体によるバックアップのもと、地域包括支 援センターに配置された生活支援コーディネーター（見守りコーディネーターを兼務）が事 
務局の中核的な機能を担い、継続する。

- 平成 30 年 9 月時点で、以下の団体がプロジェクト終了後も協議会に継続参加する意向を示 している; 町会・自治会、青少年地区委員会、民生委員児童委員協議会、志茂子ども交流館 (児童館)、シニアクラブ、子ども家庭支援センター、みずベの苑高齢者あんしんセンター（地 域包括支援センター)、志茂地域振興室、北区社会福祉協議会、スクールコーディネーター、 株式会社ほっこり〜のプラス、北区担当者（高齢福祉、子育て、教育など、各分野から担当 者を選定)。

- プロジェクト終了後も、(1)「あいさつさん」を中心とした多世代挨拶運動、(2)北社協小地域 活動拠点（通称：しもぞう八ウス）を拠点とした多世代交流の場づくり、および(3)多世代交 流を基盤とした互助の仕組みづくりに引き続き取り組むことについて、上記のメンバー間で 合意形成がされており、多世代共生・多世代共助の実現に向けた企画・検討と実装の体制が 整ったといえる。

- 北区役所、第 1 層の生活支援コーディネーターを区から受託した北区社会福祉協議会、なら びに第 2 層の生活支援コーディネーターを擁する地域包括支援センターと共に、北区におけ る今後の生活支援体制整備事業の方針等を確認しながら、プロジェクト終了後の協議会のあ り方を議論した。その結果、以下 3 つの方法をもって、第 1 層生活支援コーディネーターと 第 2 層生活支援コーディネーターの有機的な連携のあり方を提示することができた ; (1)第 1 層生活支援コーディネーターと第 2 層生活支援コーディネーターが協働して、北社協志茂地 区小地域活動拠点（通称：しもぞう八ウス）を拠点に、北区まちプロの活動を支援する、(2) 志茂ジェネ協議会（第 2 層協議体）で取り扱うテーマ等の方向性を共に検討寸る、(3)志茂ジ エネ協議会（第 2 層協議体）で見出された地域課題や、当該協議会による実践的な取り組み 等を第 1 層生活支援コーディネーターが第 1 層協議体で報告し、情報発信を行うと共に、区 の施策等に反映させる。

- 志茂ジェネ協議会を通して、活動対象世代の異なる団体間の連携、および異なる団体特性間 の連携が進みつつある。たとえば、地域包括支援センターに配置された第 2 層生活支援コー ディネーターへの聞き取り調査では、これまで連携のきっかけを得ることができなかった子 ども・子育て支援関連の団体（青少年地区委員会、志茂子ども交流館、株式会社ほっこり〜 のプラス）とつながることができた、という語りが得られた。協議会を機に、高齢者と子ど もの交流イベント・プログラムの開催など、本プロジェクト外でも協㗢事業が進んでいる。

*地域の支え合い活動を推進・支援する生活支援体制整備事業が進められている。当該事業では、 多様な生活支援・介護予防に向けた社会参加活動の創出と充実に向けて、ボランティアなどの 生活支援の担い手の養成や発掘などの地域資源の開発やそのネットワーク化などを行う生活支 援コーディネーターの配置と協議体の設立について、介護保険法の地域支援事業に位置付けた。 また、協議体と生活支援コーディネーターは基本的には 3 レベルで配置・設置が求められてい る; 市区町村全域レベルでの活動を推進寸る第 1 層協議体と生活支援コーディネーター、地域 に根付いた取り組み創出と活動支援のために、日常生活圈域（中学校区）に配置された第 2 層 生活支援コーディネーターとその活動を支援する第 2 層協議体、サービス提供主体に配置され サービスと高齢者をつなぐ第 3 層コーディネーター。

\section{【多摩区の結果・成果】}

平成 28 年 3 月より、中野島地区における地縁団体の代表者や専門職、行政職員、高齢者施設 職員、小中学校、保育園、幼稚園、研究者が参画する協議会（通称：中野島多世代つながり愛 プロジェクト）を発足し、研究期間中に 20 回開催した。毎回、多摩区役所を中心に事前打ち 
合わせから反省会を実施し、川崎市の地域包括ケアシステムの推進と多世代型のまちづくり であるプロジェクトの方向性や具体的方法の確認や調整が行われた。また、現場担当の行政 保健師と研究員、さらにはまちプロが、地域で実施する活動やプログラムに連携しながら関 わることによって、地域包括ケアシステムを基盤にしたモデルとして確立されつつある（写 真 12 )。

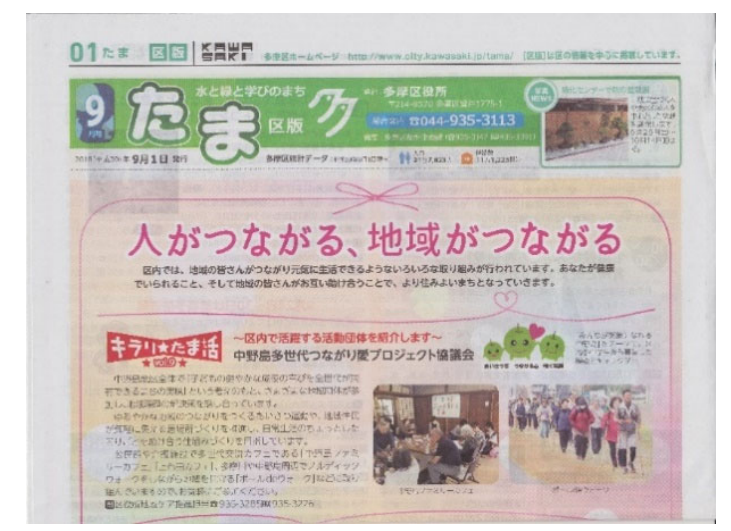

写真 12 多摩区広報2018年9月号での紹介

- 平成30年度9月、多摩区地域みまもり支援センター、地域包括支援センター、および地区社会 福祉協議会とプロジェクト終了後の体制を検討した結果、図 4の通りで継続することとなっ た。事務局機能の中核を多摩区地域みまもり支援センターが担い、地域包括支援センター、 地区社協が担い、協議会を継続することとなった。

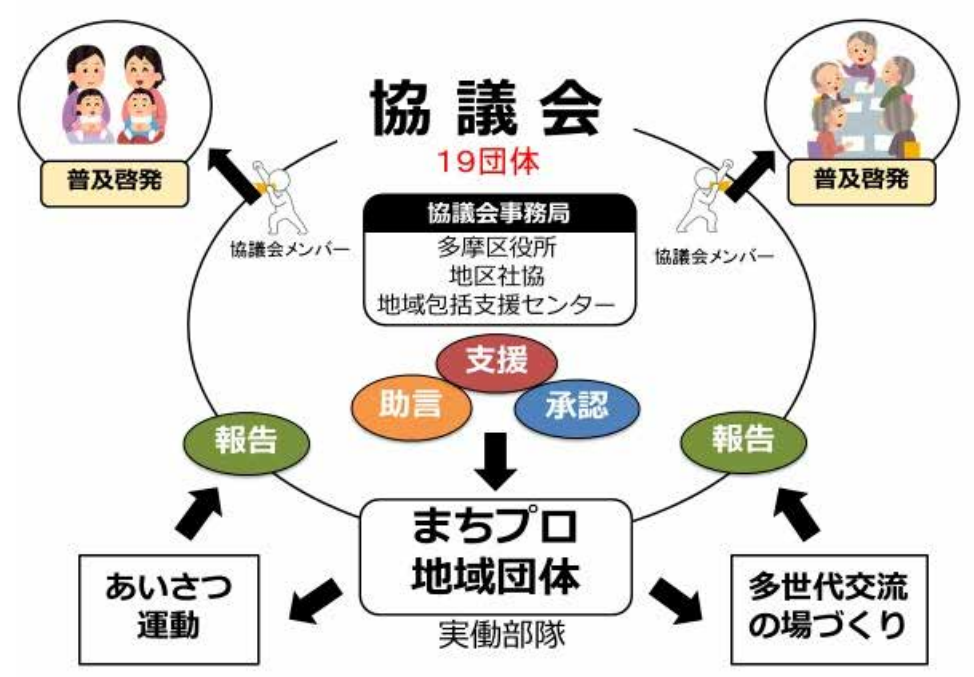

図 4 多摩区協議会体制図

- 政令指定都市の一行政区である多摩区では、川崎市が第 2 層協議会立ち上げを施策として打 ち出していない。そのため、川崎市全体に協議会という組織がない中で、横断的協議会が立 ち上がったことに対して多摩区地域みまもり支援センターからは一定の評価は得られたと考 える。

- 協議会を通して、高齢者支援担当機関である地域包括支援センターは、子ども・子育て支援 
関連機関との横断的連携が進んでいることが聞き取り調査から明らかになった。具体的には、 これまで保育園览が高齢者と交流する場合は虚弱な施設入居者（要介護 3 以上）との交流が 主であった。地域包括支援センターが関わる地域高齢者と保育園児の交流を促すイベントを 開催し、子どもにポジティブな高齢者イメージを普及することを目指している。加えて、協 議会を通して、小学校と関わることで、地域高齢者が小学校に出入りしていることを知る等、 地域高齢者の新たな把握ルートの開拓にもつながった。

- 協議会の支援のもとでまちプロが多世代交流の場「中野島ファミリーカフェ」の定期開催と そこでの互助プログラム推進を始めた。 


\section{3-5. 今後の成果の活用・展開に向けた状況}

本プロジェクトの主な成果は以下 4 点である ; (1)活動分野と活動対象世代の違いを超えた横断 的連携に基づく協議会が確立したこと、(2)協議会運営とまちプロの活動支援を通して生活支援体 制整備事業の第 1 層および第 2 層コーディネーターが地域の団体間および団体と人をつなぐ役割 を果たし始めたこと、(3)まちプロが互助に繋げることを目的とした多世代交流力フェを自主運営 し始めたこと、(4)「あいさつさん」の取り組みが協議会を基盤に地域で定着しつつあること。こ れら成果を踏まえると、以下の通りの中長期的な効果、他地区での普及可能性が期待できる。

1）中長期的な効果 ; 活動の継続と地域での広がりによる最終ビジョン達成の可能性

上記 4 つの成果は、地域に重層的な繫がりを作る住民活動の立ち上げと展開を可能とする 3 要 素をモデル地区内で確立できたともいえる ; (1)支援基盤（協議会）、(2)人材（コーディネーターと まちプロ）、(3)場等のコンテンツ（多世代交流プログラムとカフェ、およびあいさつさん活動）。 3 要素が機能した好事例として、北区志茂フィールドの「しもぞう八ウス」での活動があげられ る。協議会で世代を超えた互助を志茂地区でどのように展開するかを議論し続けた結果、常設の 場での交流から自然発生的に互助につなげるべきとの考えに至り、北区社会福祉協議会に働きか けることで拠点「しもぞう八ウス」が開設された。一方、まちプロも多世代交流力フェでの互助 を目指してはいたが、継続性の観点から会場と資金の確保が課題となっていた。協議会の支援に より「しもぞう八ウス」を無料で利用できるようになったことから安定的に多世代交流力フェを 運営できるにいたった。また、現在のまちプロだけで「しもぞう八ウス」を常時開設させること は困難との認識から、協議会・第 1 層と第 2 層生活支援コーディネーターと共に多様な地域団体 が「しもぞう八ウス」で多世代交流と互助をキーワードとした活動を展開していく方法を模索し 始めている。現時点ではまちプロによる「よりあい俱楽部」の他に絵本読み聞かせ団体が定期的 に絵本の読み聞かせを開催している。その点からも、多世代交流拠点を基盤とした互助が志茂地 区で発展することが期待できる。

地域のサポートネットワークである協議会と生活支援コーディネーターの役割が確立したこと により、志茂地区では「しもぞう八ウス」が持続すると同時に、これをモデルにした類似する拠 点が志茂地区内外で増えることが期待される。したがって、本研究が提示したロジックモデルの 短期的および中長期的アウトカムを達成寸ることができ、ひいては最終アウトカムである「子ど もの健やかな成長の喜びを全ての世代が共有できるまち」に至ると考える。

2）中長期的な効果：高齢者支援と子ども・子育て支援分野の連携による Circle of Care の確立

本プロジェクトを通して醸成された特筆すべき連携は、両モデル地区にて高齢者支援機関であ る地域包括支援センターが子ども・子育て支援の団体（北区では子ども交流館、ほっこり〜の、 および青少年地区委員会 ; 多摩区では小学校や保育園）と連携し始めたことである。地域包括支 援センターは支援を要する高齢者に対する個別支援のみならず、高齢者が地域で安心して暮らし 続けることを可能とする地域のネットワークづくり、すなわち地域包括ケアシシステムの構築の 中核的な機関として位置付けられている。また、先行研究により社会参加・社会貢献活動が高齢 者の心身の健康維持・増進に有効であることが認められていることから、地域包括支援センター は高齢者を介護予防として社会参加・社会貢献活動へ繋げることも求められている。

両モデル地区の地域包括支援センターも、地域サロンや体操グループの運営により、地域のネ ットワークづくりと高齢者の社会参加促進に取り組んできた。本プロジェクトで、子ども・子育 て支援団体と協働したことにより、地域サロンや体操グループにも「多世代」の視点を取り入れ 
ることの利点を認識できたことが聞き取り調査で示された。特に保護者を含めた 3 世代交流の良 さが指摘された。様々な活動に 3 世代交流を取り入れることで、自然な交流が発生しやすくなる こと、高齢者が役割を持てること、自然な交流と役割獲得の相乗効果として高齢者が、より楽し めることが指摘された。

今後も地域包括支援センターと子ども・子育て支援団体との横断的連携が発展すると思われる。 つまり、両モデル地区では、今後も 3 世代交流が進むことから、介護予防活動を通して高齢者の ジェネラティビティが高まることが期待できる。一方、若年世代の間では、高齢者への信頼感や 親しみが高まり、ひいては高齢者に対する見守り意識も向上すると考える。

本プロジェクトでは、高齢者世代が若年世代を支援し、高齢者が支援が必要になった際に、か つてお世話になった高齢者に若年世代が「恩返し」をする Circle of Care も重要なコンセプトと している。世代を超えた横断的連携により、Circle of Care が地域で生まれることも中長期的な効 果として期待できる。

3）都市部で多世代型地域包括ケアシステムを構築するマニュアルの作成

生活支援体制整備事業では、コーディネーターは協議体と共に住民のやる気を引き出し、やる 気になった住民の活動を支援することで、地域で多種多様な支え合い活動を生み出していく役割 が期待されている。本プロジェクトでは、多世代共創に向けた具体的な取り組みに関して協議体 で議論し続けた結果、時間は要したが地域のサポートネットワークである協議体の確立、コーデ イネーターの役割の明確化、地域人材まちプロの養成、および多世代交流プログラムと「あいさ つさん」の取り組みの定着化ができた。

この成果を他地区に普及・定着させるためにこれらのノウハウを記したマニュアルをまとめる 予定である; (1)横断的連携に基づく協議会立ち上げと運営マニュアル、(2)多世代あいさつ運動「あ いさつさん」実施マニュアル、(3)互助を促す多世代交流カフェの運営マニュアル、(4)(3)を推進す る地域人材まちプロ養成マニュアル、(5)(1)～(4)を進めるために地域資源間を調整するコーディネ ーター養成マニュアル。

北区社会福祉協議会が別地区で生活支援体制整備事業の第 2 層協議会を立ち上げる計画がある が、それに対して本プロジェクトで確立した手法を用いることを希望している。また、自治体か らも志茂ジェネの事例を区内他地区に普及啓発すること、第 2 層生活支援コーディネーターの養 成に活か寸ことが求められている。本プロジェクトで作成したマニュアルを活用し、行政施策に 連動して普及することも十分期待できる。

\section{4）新たな取り組みの課題}

多世代交流力フェ内での互助は確立しつつあるが、本プロジェクトが目指していた日常生活の 中での互助はさらに検証を進める必要がある。まず、両モデル地区の多世代交流力フェ内での互 助モデルもその手法を確立ししつあるが、未だ発展途上ともいえる。各事例の丁寧な観察と関与 者への聞き取り調査に基づき、拠点内で互助を生み出す機序、拠点内で生まれた互助を日常生活 の中での互助に発展させる方法等について検証し続ける必要がある。

また、本プロジェクトおよび大森プロジェクトを通して、支援提供主体と提供方法は、支援を求 める者の支援ニーズと依頼者の特性（健康度、人との距離感等）に応じて異なるという仮説がう まれた。そこで、拠点内に適した互助とは何か? 例えば買い物支援やゴミ出し等はどのような支 援形態が望ましいのか? といったことをさらに検証する必要もある。特に、現状民間企業が生活 支援に参入し、多様な形態の互助モデルが創りだされている。そうした中で、住民同士の互助が どのような形で進むことが、そうした民間企業によるサービスとの連携で好ましいのか検証が必 要であるかもしれない。 


\section{4. 研究開発の実施体制}

\section{4-1. 研究開発実施者}

(1)藤原佳典（研究代表者及びその率いる）グループ

\begin{tabular}{|c|l|l|l|l|}
\hline \hline 氏名 & \multicolumn{1}{|c|}{ フリガナ } & \multicolumn{1}{|c|}{ 所属機関 } & \multicolumn{1}{|c|}{ 所属部署 } & \multicolumn{1}{|c|}{$\begin{array}{c}\text { 役職 } \\
\text { (身分) }\end{array}$} \\
\hline 藤原 佳典 & フジワラ ヨシノリ & $\begin{array}{l}\text { 東京都健康長寿医 } \\
\text { 療センター研究所 }\end{array}$ & $\begin{array}{l}\text { 社会参加と地域 } \\
\text { 保健研究チーム }\end{array}$ & 研究部長 \\
\hline 南 潮 & ミナミ ウシオ & 鳥取短期大学 & $\begin{array}{l}\text { 幼览教育保育学 } \\
\text { 科 }\end{array}$ & 准教授 \\
\hline 浅見 素子 & アサミモトコ & 桜美林大学 & & 臨時職員 \\
\hline
\end{tabular}

(2)福島富士子（子育て支援）グループ

\begin{tabular}{|c|c|c|c|c|}
\hline 氏名 & フリガナ & 所属機関 & 所属部署 & $\begin{array}{l}\text { 役職 } \\
\text { (身分) }\end{array}$ \\
\hline 福島＼cjkstart富士子 & フクシマ フジコ & 東邦大学 & 看護学部 & 教授 \\
\hline 宗＼cjkstart祥子 & ムネ サチコ & $\begin{array}{l}\text { 一般社団法人日本 } \\
\text { ドゥーラ協会 }\end{array}$ & & 代表理事 \\
\hline 市川 香織 & イチカワ カオリ & $\begin{array}{l}\text { 一般社団法人産前 } \\
\text { 産後ケア推進協会 }\end{array}$ & & 代表理事 \\
\hline 米本 昌子 & ヨネモトマサコ & $\begin{array}{l}\text { 産後デイケアはあ } \\
\text { とほっと }\end{array}$ & & 代表理事 \\
\hline 松永 佳子 & マツナガ ヨシコ & 東邦大学 & 看護学部 & 准教授 \\
\hline 岸＼cjkstart恵美子 & キシ エミコ & 東邦大学 & 看護学部 & 教授 \\
\hline 増田 知実 & マスダ トモミ & $\begin{array}{l}\text { 東邦大学医療セン } \\
\text { ター大森病院 }\end{array}$ & 看護部 & 主任 \\
\hline 田嶋幸代 & タジマ サチョ & 東邦大学 & 看護学部 & 臨時職員 \\
\hline 内海千津子 & ウチウミ チズコ & $\begin{array}{l}\text { 株式会社ほっこり } \\
\text { ～のプラス }\end{array}$ & 執行本部 & 代表取締役 \\
\hline 野澤智恵子 & ノザワ チエコ & $\begin{array}{l}\text { 株式会社ほっこり } \\
\text { 〜のプラス }\end{array}$ & & 臨時職員 \\
\hline 新井可南子 & アライ カナコ & $\begin{array}{l}\text { 株式会社ほっこり } \\
\text { のプラス }\end{array}$ & & 臨時職員 \\
\hline
\end{tabular}


（3）野中久美子（生活支援）グループ

\begin{tabular}{|c|c|c|c|c|}
\hline 氏名 & フリガナ & 所属機関 & 所属部署 & $\begin{array}{l}\text { 役職 } \\
\text { (身分) }\end{array}$ \\
\hline 野中 久美子 & ノナカ クミコ & $\begin{array}{l}\text { 東京都健康長寿医 } \\
\text { 療センター研究所 }\end{array}$ & $\begin{array}{l}\text { 社会参加と地 } \\
\text { 域保健研究于 } \\
\text { 一ム }\end{array}$ & 研究員（主任） \\
\hline 倉岡＼cjkstart正高 & クラオカ マサタカ & $\begin{array}{l}\text { 東京都健康長寿医 } \\
\text { 療センター研究所 }\end{array}$ & $\begin{array}{l}\text { 社会参加と地 } \\
\text { 域保健研究于 } \\
\text { ーム }\end{array}$ & 研究員 (非常勤) \\
\hline 杉＼cjkstart啓子 & スギ ケイコ & $\begin{array}{l}\text { N P O法人日本世 } \\
\text { 代間交流協会 }\end{array}$ & & 理事長 \\
\hline 博子 & マツナガヒロコ & $\begin{array}{l}\text { 東京都健康長寿医 } \\
\text { 療センター研究所 }\end{array}$ & $\begin{array}{l}\text { 社会参加と地 } \\
\text { 域保健研究于 } \\
\text { ーム }\end{array}$ & 研究員 (非常勤) \\
\hline 田中 元基 & タナカ モトキ & $\begin{array}{l}\text { 東京都健康長寿医 } \\
\text { 療センター研究所 }\end{array}$ & $\begin{array}{l}\text { 社会参加と地 } \\
\text { 域保健研究于 } \\
\text { ーム }\end{array}$ & 研究員 (非常勤) \\
\hline
\end{tabular}

(4)渡辺修一郎 (ツール開発) グループ

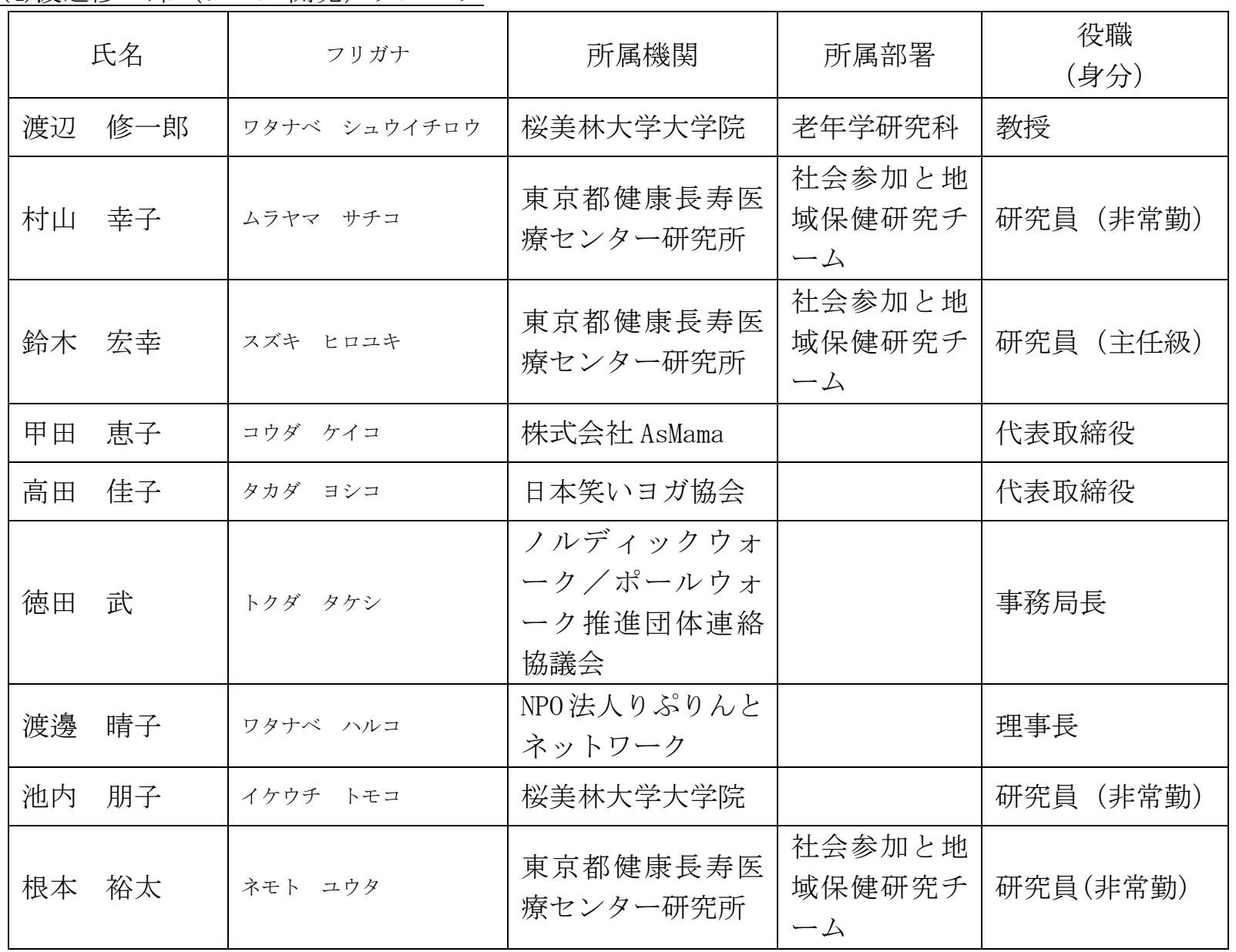


(5)稲葉陽二（事業評価）グループ

\begin{tabular}{|c|c|c|c|c|}
\hline 氏名 & フリガナ & 所属機関 & 所属部署 & $\begin{array}{l}\text { 役職 } \\
\text { (身分) }\end{array}$ \\
\hline 稲葉 陽二 & イナバ ヨウジ & 日本大学 & 法学部 & 教授 \\
\hline 小林 江里香 & コバヤシ エリカ & $\begin{array}{l}\text { 東京都健康長寿 } \\
\text { 医療センター研 } \\
\text { 究所 }\end{array}$ & $\begin{array}{l}\text { 社会参加と地域 } \\
\text { 保健研究チーム }\end{array}$ & 研究副部長 \\
\hline 村山 洋史 & ムラヤマ ヒロシ & $\begin{array}{l}\text { 東京都健康長寿 } \\
\text { 医療センター研 } \\
\text { 究所 }\end{array}$ & $\begin{array}{l}\text { 社会参加と地域 } \\
\text { 保健研究チーム }\end{array}$ & 研究員 (非常勤) \\
\hline
\end{tabular}




\section{4-2. 研究開発の協力者・関与者}

$<$ 非公開 $>$ 


\section{5. 研究開発成果の発表・発信状況、アウトリーチ活動など}

\section{5-1. 社会に向けた情報発信状況、アウトリーチ活動など}

5-1-1．情報発信・アウトリーチを目的として主催したイベント

\begin{tabular}{|c|c|c|c|c|}
\hline 年月日 & 名 称 & 場 所 & 概要・反響など & 参加人数 \\
\hline $\mathrm{H} 28 / 7 / 24$ & $\begin{array}{l}\text { 中野島音楽祭 } \\
(\text { ブース出店）}\end{array}$ & 中野島会館 & $\begin{array}{l}\text { 中野島地区で毎年開催 } \\
\text { されている地域イベン } \\
\text { トにて、本プロジェク } \\
\text { トの広報のためのブー } \\
\text { スを出店した。 }\end{array}$ & 約 80 名 \\
\hline $\mathrm{H} 28 / 9 / 5$ & $\begin{array}{l}\text { 志茂ジェネ キック } \\
\text { オフイベント }\end{array}$ & $\begin{array}{l}\text { 志茂東ふれあい } \\
\text { 館 }\end{array}$ & $\begin{array}{l}\text { 本プロジェクトの普及 } \\
\text { 啓発を主な目的として } \\
\text { 行われた多世代交流イ } \\
\text { ベント。公開講座と交 } \\
\text { 流イベント（絵本ライ } \\
\text { ブ）の二部構成で実施 } \\
\text { した。 }\end{array}$ & 25 名 \\
\hline H28/11/19 & $\begin{array}{l}\text { 志茂はっぴい祭り } \\
(\text { ブース出店) }\end{array}$ & $\begin{array}{l}\text { 志茂子ども交流 } \\
\text { 館 }\end{array}$ & $\begin{array}{l}\text { 志茂子ども交流館で毎 } \\
\text { 年開催されているイベ } \\
\text { ントに志茂ジェネとし } \\
\text { て初めてブースを出店 } \\
\text { した。プロジェクトの } \\
\text { PR グッズ配布と、ロゴ } \\
\text { マークの表彰を実施。 }\end{array}$ & $\begin{array}{l}\text { 親子連れな } \\
\text { ど約 } 100 \text { 組 } \\
\text { (ブース来 } \\
\text { 場者数) }\end{array}$ \\
\hline $\mathrm{H} 28 / 12 / 3$ & $\begin{array}{l}\text { 中野島地区社協 } \\
\text { 社 } \\
\text { 会福祉のつどい }\end{array}$ & 中野島小学校 & $\begin{array}{l}\text { 中野島地区社協が主催 } \\
\text { するイベントにて、ロ } \\
\text { ゴマークの優秀賞の授 } \\
\text { 賞式を実施した。 }\end{array}$ & 不明 \\
\hline $\mathrm{H} 29 / 1 / 16$ & $\begin{array}{l}\text { 中野島多世代助け合 } \\
\text { いキックオフイベン } \\
\text { ト }\end{array}$ & $\begin{array}{l}\text { 中野島団地集会 } \\
\text { 所 }\end{array}$ & $\begin{array}{l}\text { まちプロ研修のキック } \\
\text { オフイベントとして、 } \\
\text { プロジェクトの紹介、 } \\
\text { 絵本うたのライブ、食 } \\
\text { 事会を実施した。 }\end{array}$ & 23 名 \\
\hline H29/7/29 & $\begin{array}{l}\text { 中野島音楽祭 } \\
(\text { ブース出店) }\end{array}$ & 中野島会館 & $\begin{array}{l}\text { ブースを出店し、本プ } \\
\text { ロジェクトの周知なら } \\
\text { びに } 9 \text { 月より実施予定 } \\
\text { であったノルディック } \\
\text { ウォークイベントの広 } \\
\text { 報活動を実施した。 }\end{array}$ & 約 100 名 \\
\hline
\end{tabular}




\begin{tabular}{|c|c|c|c|c|}
\hline $\mathrm{H} 29 / 9 / 3$ & $\begin{array}{c}\text { 多摩川住宅防災訓練 } \\
\text { (ブース出店） }\end{array}$ & 中野島中央公園 & $\begin{array}{l}\text { 多摩川住宅近隣の住民 } \\
\text { が参加する防災訓練に } \\
\text { ブースを出店し、防災 } \\
\text { 訓練の前後でプロジェ } \\
\text { クトの広報やイベント } \\
\text { の告知を行った。 }\end{array}$ & 約 200 名 \\
\hline H29/9/10 & $\begin{array}{l}\text { 北区つながり創造プ } \\
\text { ロジェクト } \\
\text { (ブース出店 })\end{array}$ & $\begin{array}{l}\text { ダイエー赤羽店 } \\
\text { 前 }\end{array}$ & $\begin{array}{l}\text { 青年会議所北区委員会 } \\
\text { 主催の北区つな゙り創 } \\
\text { 造プロジェクトに、志 } \\
\text { 茂ジェネのブースを出 } \\
\text { 店した。子どもたちが } \\
\text { 居住地域に関心を持 } \\
\text { ち、将来的に支え手に } \\
\text { なってほしいという希 } \\
\text { 望から、様々な地域活 } \\
\text { 動をクイズ形式で紹介 } \\
\text { した。 }\end{array}$ & $\begin{array}{l}84 \text { 名 } \\
\text { (ブース来 } \\
\text { 場者数 })\end{array}$ \\
\hline $\begin{array}{l}\mathrm{H} 30 / 2 / 23,2 / \\
24\end{array}$ & $\begin{array}{c}\text { 北区子育てメッセ } \\
\text { (ブース出店) }\end{array}$ & 北とぴあ & $\begin{array}{l}\text { 東京都北区・子育てマ } \\
\text { マ応援塾ほっこり〜の } \\
\text { 主催のイベントに、志 } \\
\text { 茂ジェネのブースを出 } \\
\text { 店した。まちプロと共 } \\
\text { に、手作りひな飾りの } \\
\text { コーナーを設け、来場 } \\
\text { した親子連れとの交流 } \\
\text { と活動の PRを行った。 }\end{array}$ & $\begin{array}{l}50 \text { 名 } \\
\text { （ブース来 } \\
\text { 場者） }\end{array}$ \\
\hline H30/7/21 & 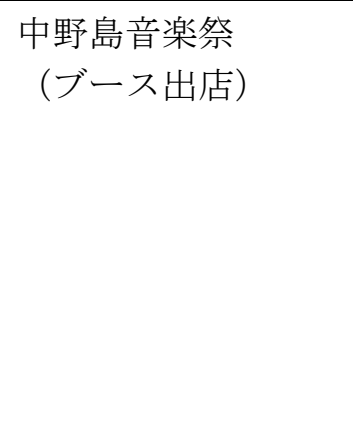 & 中野島会館 & $\begin{array}{l}\text { ブースを出店し、本プ } \\
\text { ロジェクトの周知を行 } \\
\text { った。ブースでは風船 } \\
\text { を使った工作やロゴマ } \\
\text { ークが入ったうちわを } \\
\text { 配布し、多くの子育て } \\
\text { 世代に広報することが } \\
\text { できた。 }\end{array}$ & 約 100 名 \\
\hline
\end{tabular}




\section{5-1-2. 研究開発の一環として実施したイベント}

\begin{tabular}{|c|c|c|c|c|}
\hline 年月日 & 名 称 & 場 所 & 概要・反響など & 参加人数 \\
\hline $\mathrm{H} 28 / 11 / 14$ & 青猫書房保活講座 & 青猫書房 & $\begin{array}{l}\text { 株式会社ほっこり〜の } \\
\text { プラスと志茂ジェネの } \\
\text { 共催イベント。「保活」 } \\
\text { (子どもを保育所に入 } \\
\text { れるための活動) につ } \\
\text { いて、地域の子育て世 } \\
\text { 代向けに講座を開い } \\
\text { た。ま、地域の子育て } \\
\text { 世代のニーズ調査もあ } \\
\text { わせて実施した。 }\end{array}$ & $\begin{array}{l}\text { 親子連 れ } \\
12 \text { 組 }\end{array}$ \\
\hline $\mathrm{H} 29 / 2 / 20$ & $\begin{array}{l}\text { 地域の魅力再発見！ } \\
\text { 志茂二丁目まち歩き }\end{array}$ & $\begin{array}{l}\text { 志茂二丁目（商店 } \\
\text { 街、町会の会館な } \\
\text { ど） }\end{array}$ & $\begin{array}{l}\text { 異なる世代同士が組と } \\
\text { なって、志茂二丁目の } \\
\text { 商店街を一緒に巡るイ } \\
\text { ベントを開催。和菓子 } \\
\text { 屋や、志茂名物のちく } \\
\text { わぶ工場「川口屋」の見 } \\
\text { 学をした後、志茂二丁 } \\
\text { 目町会の会館にて食事 } \\
\text { をしながら交流を行っ } \\
\text { た。 }\end{array}$ & 34 名 \\
\hline $\mathrm{H} 29 / 3 / 30$ & $\begin{array}{l}\text { 多世代で楽しむコン } \\
\text { ディショニング教室 }\end{array}$ & $\begin{array}{l}\text { 北区立元気ぷら } \\
\text { ざ }\end{array}$ & $\begin{array}{l}\text { NCA（日本コンディシ } \\
\text { ョニング協会）認定ト } \\
\text { レーナーを講師に迎 } \\
\text { え、コンディショニン } \\
\text { グ教室を開催。シニア } \\
\text { と子育て世代がペアと } \\
\text { なり、お互いに体操の } \\
\text { 補助をしながら交流を } \\
\text { 楽しんだ。 }\end{array}$ & 22 名 \\
\hline $\mathrm{H} 29 / 7 / 4$ & $\begin{array}{l}\text { 多世代でつながる・ } \\
\text { ささえる 志茂三丁 } \\
\text { 目防災イベント }\end{array}$ & $\begin{array}{l}\text { 志茂三丁目（小柳 } \\
\text { 川公園、自治会の } \\
\text { 会館など） }\end{array}$ & $\begin{array}{l}\text { 異なる世代でチームを } \\
\text { 作り、防災知識を学び } \\
\text { ながらスタンプラリー } \\
\text { を楽しんだ。志茂三丁 } \\
\text { 目自治会の会館で非常 } \\
\text { 食 (アルファ米) の試食 } \\
\text { 等をしながら、参加者 } \\
\text { 同士の交流も行った。 }\end{array}$ & 19 名 \\
\hline
\end{tabular}




\begin{tabular}{|c|c|c|c|c|}
\hline H30/2/24 & $\begin{array}{l}\text { 中野島つながり愛フ } \\
\text { オーラム }\end{array}$ & $\begin{array}{l}\text { 川崎市多摩区中 } \\
\text { 野島・中野島会館 }\end{array}$ & $\begin{array}{l}\text { 本プロジェクトの普及 } \\
\text { 啓発と新たな手発 } \\
\text { 掘のため、報告会とワ } \\
\text { ークショップを合わせ } \\
\text { たフォーラムを実施し } \\
\text { た。様々な地域の課題 } \\
\text { やこれから取り組みと } \\
\text { して期待することなど } \\
\text { があげられた。 }\end{array}$ & 69 名 \\
\hline H30/3/3 & $\begin{array}{l}\text { 第 } 1 \text { 回 志茂ジェネ } \\
\text { まつり〜多世代 (み } \\
\text { んな) で楽しむひな } \\
\text { 祭り〜 }\end{array}$ & $\begin{array}{l}\text { 北区志茂東ふれ } \\
\text { あい館 }\end{array}$ & $\begin{array}{l}\text { 多世代交流や多世代共 } \\
\text { 生の重要性を地域住民 } \\
\text { に広く啓発することを } \\
\text { 目的に、地域住民や団 } \\
\text { 体の有志からなるイべ } \\
\text { ントを開催した。ひな } \\
\text { 人形との記念撮影や桜 } \\
\text { もち作り、お茶点てな } \\
\text { ど、世代を越えて楽し } \\
\text { める体験コーナーを設 } \\
\text { 置。 }\end{array}$ & 99 名 \\
\hline
\end{tabular}

\section{5-1-3．書籍、DVD など論文以外に発行したもの}

なし

\section{5-1-4. ウェブメディア開設・運営}

(1)Facebook ページ「ジェネラティビティで紡ぐ地域多世代共助（@ ristexgenerativity）」

URL : https://www.facebook.com/ristexgenerativity, 2016 年 1 月開設，リーチ数 10,403、フ オロワー数 117 (平成 29 年 4 月 1 日〜平成 30 年 9 月 30 日)

(2)ウェブサイト「志茂ジェネ〜世代をつむぐプロジェクト〜」

URL : https://i10vinkotobuki.wixsite.com/mysiteshimogene, 2017 年 4 月開設，無料作成サー ビスを使用のため、アクセス数は不明

\section{5-1-5. 学会以外 (5-3. 参照) のシンポジウムなどでの招へい講演など}

口平成 30 年度

（1）「平成 30 年度 高齢社会フォーラム in 八戸」，基調講演『高齢者から発進！世代をつむぐ，三 方よしの地域づくり』。内閣府 , 2018.10.12, 八戸

口平成 29 年度

(2)「2017 北区コミュニティビジネス シンポジウム：やりがい・生きがいをみつけ地域が元気に なる仕事」，事例報告『志茂ジェネ ～世代をつむぐプロジェクト〜 ジェネラティビティで紡ぐ 
重層的な地域多世代共助システムの開発』. 北区／NPO 法人コミュニティビジネスサポートセン ター, 2017.7.13, 東京

（3）「平成 29 年度 王子圈域地域包括ケア連絡会」，事例報告・グループワーク『多世代コミュニ ティの構築を目指して〜子育て世代も子育て卒業世代も本音で語り合おう〜』. 王子圈域地域包 括支援センター, 2017.9.29, 東京

（4）「平成 29 年度 高齢社会フォーラム in 宮崎」，基調講演『高齢者から発進！世代をつむぐ，三 方よしの地域づくり』.内閣府, 2017.10.6, 宮崎

(5)「城北 6 区 第 2 回健康寿命延伸支援ビジネス普及啓発セミナー」，講演『高齢者の社会参加が 導く「三方よし」，高齢者の社会参加と中小企業戦略～』. 東京商工会議所城北支部, 2017.10.25, 東京

（6）「平成 29 年度 十条台地域包括ケア連絡会」，事例報告・グループワーク『みんなでつくる，見 守り・ささえあい 〜近助（近隣での助けあい）について考える〜』.十条台地域包括支援センタ 一, 2017.11.29, 東京

（7）「平成 29 年度 高齢社会フォーラム in 東京」，基調講演『高齢者から発進！世代をつむぐ，三 方よしの地域づくり』.内閣府, 2018.1.22, 東京

（8）「平成 29 年度 第 3 回みずべの苑地域包括ケア連絡会」，事例報告・グループワーク『まごこ ろあふれる “志茂のまち” 近助（近隣での助け合い）について考えよう』。みずべの苑地域包括 支援センター, 2018.3.14, 東京

口平成 28 年度

(9)「平成 28 年度 多摩区地域包括ケアシステムシンポジウム」，講演『多世代でつむぐ支え合い のまち 多摩区』.多摩区役所主催, 2017.2.13, 川崎市多摩区

\section{5-2. 論文発表}

\section{5-2-1. 查読付き（ 8 件）}

口平成 30 年度

(1)南 潮, 望月美希, 長谷部雅美, 野中久美子, 倉岡正高, 村山幸子, 藤原佳典, 地域活動として の学習支援事業を運営・管理する観点の抽出と世代循環の仕組みの意識に関する実態調査,

日本世代間交流学会誌８(1) 23-30２018 年 10 月

（2)根本裕太，倉岡正高，野中久美子，田中元基，村山幸子，松永博子，安永正史，小林江里香, 村山洋史, 渡辺修一郎, 稲葉陽二, 藤原佳典, 若年層と高年層における世代内／世代間交流と精 神的健康状態との関連，日本公衆衛生雑誌（印刷中）

（3)小林江里香，野中久美子，倉岡正高，松永博子，村山幸子，田中元基，根本裕太，村山洋史， 渡辺修一郎, 稲葉陽二, 藤原佳典: 「地域の子育て支援行動尺度」の多世代一の適用可能性と支援 行動の世代別特徵. 日本公衆衛生雑誌, 65(7), 321-333, 2018. doi:10.11236/jph.65.7_321

平成 29 年度

(4)藤原佳典:高齢者のシームレスな社会参加と健康の関連 日本福祉教育・ボランティア学習学会 研究紀要 21-34,2017（查読あり）29(1)

(5)倉岡正高 : 多世代循環型社会の構築に向けて一仕組みと仕掛けの社会実装一. 日本福祉教育・ボ ランティア学習学会研究紀要:99-108, 2017 (査読あり) 
口平成 28 年度

(6)藤原佳典 : 多世代の互助・共助による社会システムは構築できるか? 一持続可能な社会の処方 箋“Positive spiral of care”を目指して一。 日本世代間交流学会誌，6(1),3-8,2017（1 月）

（7)倉岡正高,長谷部雅美, 野中久美子, 村山陽, 安永正史, 南潮, 藤原佳典 : 多世代循環型社会にお ける世代間交流の実装の要件と可能性の検討，日本世代間交流学会誌, 6(1),69-74,2017（1 月）

(8)村山幸子・松永博子・倉岡正高・野中久美子・藤原佳典, あいさつ運動に関する文献レビュー 効果に関する理論的考察と先進事例からみる活動上の工夫と課題. 日本世代間交流学会誌, 6(1), $75-82,2017$ (1 月)

\section{5-2-2. 査読なし（ 1 件）}

(1)藤原佳典 : 高齢者の社会参加が導く持続可能な互助コミュニティ聖路加看護学会誌,2017（查 読なし） 21(2)

\section{5-3. 口頭発表（国際学会発表及び主要な国内学会発表）}

\section{5-3-1. 招待講演（国内会議 2 件、国際会議 1 件}

\section{口平成 29 年度}

(1)藤原佳典 : 特別講演 : 高齢者の社会参加が導く、持続可能な互助コミュニティ第 22 回聖路加 看護学会学術大会，東京，2017.9.16

(2)藤原佳典 :「富山大学 地域連携推進機構 地域医療・保健支援部門 10 周年記念講演」『高齢 者から発進！多世代で紡ぐ、三方よしの地域づくり』富山大学 地域連携推進機構 地域医療・ 保健支援部門、富山市、2017.12.2

口平成 28 年度

(3) Masataka Kuraoka, "Promoting Multigenerational Cyclical Support System in Japanese Community", Intergenerational Contact Zones in Asian Context: a focus on education and integrated service spaces, Singapore, 2017.3.3.

\section{5-3-2. 口頭発表国内会議 10 件、国際会議 0 件)}

口平成 30 年度

（1)根本裕太，倉岡正高，野中久美子，田中元基，村山幸子，安永正史，小林江里香，村山洋史， 藤原佳典, 若年層と高年層における世代内／世代間交流と精神的健康状態との関連，第 60 回日本 老年社会科学会大会, 東京, 2018 年 6 月 10 日

\section{口平成 29 年度}

(2)藤原佳典: シンポジウム 高齢者支援と子ども・子育て支援の連携によるソーシャルキャピタ ル戦略一多世代型互助システムの構築一導入編,第 76 回日本公衆衛生学会総会, 鹿児島 2017.10.31-11.2

（3）野中久美子:多世代型相互扶助モデル「くらしシェア」の概要.日本公衆衛生学会, 鹿児 島,2017.10.31-11.2 
口平成 28 年度

(4)藤原佳典:「ジェネラティビティで紡ぐ重層的な地域多世代共助システムの開発」プロジェクト がめざすもの.シンポジウム，第 7 回日本世代間交流学会，東京，2016.10.8

(5)藤原佳典：自主企画シンポジウム（企画者・話題提供者）多世代型交流・互助システムの概要. 『多世代共生コミュニティ構築にむけた重層的なコミュニケーションアプローチの展望 : JSTRISTEX「持続可能な多世代共創社会のデザイン」研究開発領域より』第 11 回日本応用老年学会, 大阪，2016.10.29

（6)村山幸子（東京都健康長寿医療センター研究所 社会参加と地域保健研究チーム），日常的な 声かけなどによる緩やかなサポートネットワーク。自主企画シンポジウム A「多世代共生コミュ ニティ構築にむけた重層的なコミュニケーションアプローチの展望 : JST-RISTEX『持続可能な 多世代共創社会のデザイン』研究開発領域より」。第 11 回日本応用老年学会大会，大阪， 2016.10.29

(7)野中久美子,「ジェネラティビティで紡ぐ重層的な地域多世代共助システムの開発」プロジェク トの概要 : 多世代相互扶助モデルのプラットフォームと緩やかなネットワークづくり。シンポジ ウム，第 7 回日本世代間交流学会，東京, 2016.10.28

（8)野中久美子，「重層的な地域多世代共助システム」：多世代のプラットホームとネットワークづ くり. 公募シンポジウム「高齢者支援と子育て支援は連携できるか? 多世代型地域互助システム に向けて．第 74 回日本公衆衛生学会総会, 大阪, 2016.11.26-27.

(9)倉岡正高,野中久美子,安永正史,藤原佳典: 高齢者による地域の子育て支援行動とジェネラティ ビティの関係性，第 7 回日本世代間交流学会，東京都大田区, 2016.10.8

(10)倉岡正高，多世代共創社会の構築にむけて：仕掛けと仕組みの社会実装，第 22 回日本福祉教 育・ボランティア学習学会, 宮崎県都城市, 2016.11.25-27

5-3-3. ポスター発表 （国内会議 20 件、国際会議 3 件）

口平成 30 年度

（1)村山幸子，小林江里香，野中久美子，倉岡正高，安永正史，田中元基，根本裕太，松永博子，渡 辺修一郎，藤原佳典：世代性の規定要因に関する探索的検討：都市部高齢者を対象とした調査か ら. 日本老年社会科学会第 60 回大会, 東京, 2018.6.9-6.10

(2)倉岡正高，野中久美子，安永正史，藤原佳典: 小学生のあいさつと高齢者に対するイメージの関 連について. 第 9 回日本世代間交流学会, 兵庫, 2018.10.6

(3)倉岡正高，野中久美子，村山幸子，田中元基，根本裕太，小林江里香，藤原佳典 : ジェネラティ ビティと精神的健康状態の関連について. 第 77 回日本公衆衛生学会総会, 郡山, 2018.10.2410.26

(4)村山幸子，野中久美子，倉岡正高，田中元基，根本裕太，小林江里香，藤原佳典：住民参加型ワ ークショップ「お互いさまゲーム」の開発 : 生活支援ニーズの質的分析. 第 77 回日本公衆衛生学 会総会，郡山, 2018.10.24-10.26

（5）田中元基，野中久美子，倉岡正高，村山幸子，根本裕太，藤原佳典：多様な関係主体から成る協 議体の質的分析 : 参加者の会議内容理解の低い会議の特徴. 第 77 回日本公衆衛生学会総会, 郡山, 2018.10.24-26

(6)Kuraoka M, Nonaka K, Sachiko M., Tanaka, M., Nemoto, Y., Kobayashi, E.,Fujiwara Y: Older Adult's Self-Perception of Generativity and their Daily Activity in Japan, Gerontological Society of America, Boston, 2018.11.14-18 
（7)倉岡正高，野中久美子，村山幸子，田中元基，根本裕太，小林江里香，藤原佳典：ジェネラティ ビティと世代間の信頼の関連について, 第 24 回日本福祉教育・ボランティア学習学会全国大会, 名古屋, 2018.11.24-25

\section{平成 29 年度}

(8)村山幸子,小林江里香,倉岡正高,野中久美子,安永正史,田中元基,根本裕太,箕浦明,松永博子,村山 洋史, 藤原佳典 : ジェネラティビティの構成要因と関連要因についての探索的検討一都市部高齢者 を対象とした郵送調査の結果から一.第 59 回日本老年社会科学会大会,名古屋,2017.6.14-16

(9)野中久美子,村山洋史,倉岡正高,村山幸子,田中元基,安永正史,根本裕太,松永博子,渡辺修一郎,小 林江里香,藤原佳典 : 有償生活支援サービスのニーズと生活機能の関連.第 58 回日本老年社会科学 会大会,名古屋,2017. 6.14 6.16

（10）田中元基,小林江里香,野中久美子,村山洋史,倉岡正高,村山幸子,安永正史,根本裕太,松永博子, 箕浦明,藤原佳典 : 高齢者間の世代差から見た他世代との日常生活における支援の授受の検討.第 59 回日本老年社会科学会大会, 名古屋,2017.6.14-16

(11)渡辺修一郎, 藤原佳典, 小林江里香, 野中久美子, 倉岡正高, 箕浦明, 松永博子, 村山幸子, 南潮, 小池 高史,稲葉陽二: 都市部高齢者の就労および求職状況と高次生活機能との関連. 日本老年社会科学会 第 59 回大会,名古屋,2017.6.14-16.

(12)藤原佳典,倉岡正高:大都市部における育児と介護のダブルケアとソーシャルキャピタルの関 連,日本世代間交流学会第 8 回大会, 熊本, 2017.10 .7

(13)倉岡正高,藤原佳典 : 子育て支援行動を受けた経験と地域に対する意識について.日本世代間交 流学会第 8 回全国大会,熊本学園大学, 2017.10.

（14）田中元基,野中久美子, 倉岡正高,村山幸子,根本裕太, 藤原佳典 : 介護予防 - 日常生活支援総合事 業における多様な関係主体から成る協議体の分析 : 意思決定プロセスの質的分析.第 12 回日本応 用老年学会大会, 東京, 2017.10 .22

(15)藤原佳典,野中久美子, 倉岡正高, 松永博子, 村山幸子, 田中元基, 根本裕太,村山洋史, 渡辺修一郎, 松永佳子, 福島富士子, 小林江里香: 大都市部におけるダブルケアの実態と多世代間の支援の関連, 第 76 回日本公衆衛生学会総会, 鹿児島, 2017.10.31-11.2

（16）小林江里香,野中久美子,倉岡正高,松永博子,村山幸子,田中元基,根本裕太,村山洋史,渡辺修一郎, 松永佳子,藤原佳典：性・年齢層別にみた地域の子育て支援行動の実施状況と関連要因.第 76 回日 本公衆衛生学会総会,鹿児島,2017.10.31-11.2

(17)倉岡正高,野中久美子,村山幸子,田中元基,根本裕太,渡辺修一郎,藤原佳典 : 多世代共助システム

(よりあい)の開発と社会実装の検証に向けて.第 76 回日本公衆衛生学会総会,鹿児島,2017.10.3111.2

（18)村山幸子,倉岡正高,野中久美子,田中元基,根本裕太,安永正史,小林江里香, 村山洋史, 藤原佳典: 児童・生徒の挨拶習慣が居住地域の暮らしやすさと援助行動へ及ぼす影響.第 76 回日本公衆衛生 学会総会,鹿児島,2017.10.31-11.2

（19）田中元基，野中久美子，倉岡正高，村山幸子，根本裕太，石井義之，安永正史，箕浦明，松永 博子, 渡辺修一郎，松永佳子，福島富士子，藤原佳典:多様な立場・専門領域を持つ人々から成る 会議体における議案進行方法の特徴.第 76 回日本公衆衛生学会総会,鹿児島,2017.10.31-11.2

(20)Kuraoka M; Designing Multigenerational Co-creation Community: Developing community-based interventions and the practice in Japan, Generations United, Milwaukee,USA, 2017.6.13-16

(21)Kuraoka M, Hasebe M, Nonaka K, Yasunaga M,Fujiwara Y: Effective Community-Based Program for Multigenerational Cyclical Support System. IAGGSan Francisco2017.7.23-27 
平成 28 年度

(22)村山幸子 - 松永博子 - 倉岡正高 - 野中久美子 - 石井義之 - 田中元基 - 安永正史 - 渡辺修一郎 松永佳子・福島富士子・藤原佳典, 重層的な地域多世代共助システムの開発 $(2)$ : 挨拶運動とキャ ンペーンの展開. 第 75 回日本公衆衛生学会総会, 大阪, 2016.10 .27

（23)倉岡正高，野中久美子，村山幸子，石井義之，田中元基，安永正史，松永博子，渡辺修一郎，松 永佳子, 福島富士子, 藤原佳典: 重層的な地域多世代共助システムの開発(1) : 多世代相互支援推進 協議会の運営, 第 75 回日本公衆衛生学会総会, 大阪, 2015.10.24-26

\section{5-4. 新聞報道・投稿、受賞など}

\section{5-4-1．新聞報道・投稿}

(1)タウンニュース川崎多摩区版,2018 年 10 月 5 日号、『中野島プロジェクト新体制 30 人規模に 独立事業で再始動』, https://www.townnews.co.jp/0203/2018/10/05/451525.html

(2)タウンニュース川崎多摩区版,2018 年 9 月 28 日号、『広がる多世代のふれあい』, https://www.townnews.co.jp/0203/2018/09/28/450494.html

(3)タウンニュース川崎多摩区版,2018 年 3 月 9 日号, 『多世代で未来描こう』, https://www.townnews.co.jp/0203/2018/03/09/422822.html

(4)ベターケア 『地域共生社会をどうつくる?』芳林社、2017.10.31

\section{5-4-2. 受賞}

(1)第 76 回日本公衆衛生学会鹿児島大会ポスター賞 : 村山幸子,倉岡正高,野中久美子,田中元基,根 本裕太,安永正史, 小林江里香, 村山洋史, 藤原佳典: 児童・生徒の挨拶習慣が居住地域の暮らしや すさと援助行動へ及ぼす影響.第 76 回日本公衆衛生学会総会,鹿児島,2017.10.31-11.2

(2)第 77 回日本公衆衛生学会福島大会優秀ポスター賞：倉岡正高，野中久美子，村山幸子，田中 元基, 根本裕太, 小林江里香, 藤原佳典 : ジェネラティビティと精神的健康状態の関連について. 第 77 回日本公衆衛生学会総会, 郡山, 2018.10.24-10.26

\section{5-4-3. その他}

（1)たま区報平成 30 年 9 月 1 日発行 1 面 『人がつながる、地域がつながる』にて紹介

(2)J:COM「東京北人図鑑」インタビュー（第 37 回 2018 年 1 月 22 日放送）にて紹介 (YouTube でアーカイブを視聴可能)

J:COM ホームページ URL : https://jinzukan.myjcom.jp/tokyokita/post/346

YouTube URL : https://www.youtube.com/watch?v=NnimwE3QHP8

※その他、J:COM ニュース内で「志茂二丁目まち歩き」の様子を放映

\section{$5-5$. 特許出願}

\section{5-5-1. 国内出願（ 0 件）}

なし

5-5-2. 海外出願（ 0 件）

なし 